\title{
Effektbaserede ressourcetildelingsmodeller for forløbs- og periodebaserede indsatser i den offentlige sektor ${ }^{\mathrm{i}}$
}

\author{
Af Per Nikolaj Bukh og Karina Skovvang Christensen *)
}

\section{Resumé}

Tildelingsmodeller er budgetmodeller, der tildeler ressourcer fra et overliggende styringsniveau til decentrale udførerenheder ved anvendelse af matematiske formler. De er baseret på tildelingskriterier, der kan omfatte både cost-drivere og resultatmål. Denne form for budgetmodel vil altid udgøre en incitamentsstruktur. Effektbaserede tildelingsmodeller er karakteriseret ved, at de indebærer incitamenter, der fremmer effektskabelse. I denne artikel tager vi udgangspunkt i, hvordan produktions- og økonomistrukturer på forskellige serviceområder har betydning for, hvordan en tildelingsmodel bedst designes. Vi sætter især fokus på forløbs- og periodebaserede indsatser på ældreområdet samt på handicap- og psykiatriområdet. Begge områder er karakteriseret ved, at opgaverne primært udføres af offentlige virksomheder, og hvis de udføres i privat regi, finansieres de oftest af det offentlige. Herefter ser vi på tildelingsmodellers motiverende egenskaber og diskuterer, hvornår de indeholder incitamenter til effekt. Endelig skitserer vi grundprincipperne for effektbaserede tildelingsmodeller. Med afsæt i konkrete erfaringer fra bl.a. Odense Kommune viser vi, hvordan der kan udvikles effektbaserede økonomistyringsmodeller for korte og intensive rehabiliteringsforløb. Herudover diskuterer vi karakteristika ved den økonomiske styring af længerevarende eller permanente indsatser, og det illustreres, hvordan der kan anvendes forløbsbevillinger på dette område.

\section{Emneord}

Effekt, forløbsstyring, incitamenter, ledelsesrum, lighed, motivation, omkostningseffektivitet, omsætningsstruktur, produktionsstruktur, tildelingsmodeller, økonomistyring, økonomistruktur

*) Per Nikolaj Bukh er cand.oecon. og ph.d. samt professor i økonomistyring ved Aalborg Universitet. Karina Skovvang Christensen er cand.oecon. og ph.d. samt lektor ved Institut for Økonomi, Aarhus Universitet. 


\section{A. Indledning}

\section{Artiklens baggrund}

Man kan skrive om økonomistyring ud fra mange perspektiver. Det kan f.eks. være et spørgsmål om at forstå, hvilke konsekvenser styringen har for organisationen eller for medarbejderne; eller det kan være et spørgsmål om, hvordan en bestemt økonomistyringsteknik skal anvendes eller indføres. Når man ud fra et driftsøkonomisk perspektiv beskæftiger sig med økonomistyring, vil man ofte være interesseret i, hvilke økonomistyringsteknikker der i en given situation fungerer bedst, samt hvordan mere generelle teknikker bør anvendes i konkrete situationer. Økonomistyring er dermed et spørgsmål om at sikre realiseringen af virksomhedens mål, og økonomistyring er næsten synonym med det interne regnskabs styrings- og informationsbehandlingsformål (Melander 1994). Ud fra dette perspektiv er det derfor mere eller mindre eksplicit, at økonomistyring er et ledelsesredskab, som løser et styringsbehov, og at ledelsen udgør en privilegeret aktør, der bestemmer, hvordan økonomistyringen skal indrettes for at opnå en eller flere målsætninger (Chenhall 2007, p. 164) ud fra et situationsbetinget perspektiv (jf. Mouritsen 1987).

I enhver virksomhed kan man vælge mellem mange forskellige økonomistyringsteknikker. Hvilke, der er relevante, afhænger af, hvilken virksomhedstype der er tale om, samt hvilke målsætninger der er med virksomhedens aktiviteter. De konkrete teknikkerne skal derfor anvendes forskelligt i forskellige situationer. Der er imidlertid også andre årsager end forskelle i målsætninger til, at virksomheder ikke anvender samme økonomistyringsteknikker. Der kan f.eks. være store forskelle i den kompleksitet, store og små virksomheder står overfor, hvorfor behovet for økonomistyring også er forskelligt. Sådanne forskelle mellem virksomheder blev adresseret af de organisationsteoretiske klassikere (Burns \& Stalker 1961; Thomson 1967; Galbraith 1973), der især fokuserede på, hvordan omgivelser og teknologi påvirker organisationsstrukturen. På tilsvarende vis bidrog den tidligere situationsbestemte ('contingency') økonomistyringslitteratur (Otley 1980) med en forståelse for, hvordan centrale variable påvirker økonomistyringens design.

De økonomistyringsteknikker, der kan anvendes i den offentlige sektor, er i princippet ikke anderledes end dem, der anvendes i private virksomheder. Der kan være aktiviteter, der oftest eller altid udføres i offentlige regi, og offentlige virksomheder har oftest til en vis grad andre målsætninger end private virksomheder. Disse forskelle skal der naturligvis tages højde for, når økonomistyringen designes, og når teknikker anvendes i den offentlige sektor. De løbende ændringer i den offentlige sektor såvel som skiftende reformer medfører nye opgaver og nye målsætninger. Dermed opstår der både behov for ændringer af den bestående økonomistyring og behov for at udvikle og anvende nye økonomistyringsteknikker. Blandt de centrale ændringer i den offentlige sektor er ikke blot det forøgede fokus på effekt, men også en større erkendelse af, at de mest omfattende og dyreste løsninger ikke altid er de bedste. Eksempelvis kan kortvarige intensive 
rehabiliteringsindsatser i nogle situationer være den fagligt set bedste løsning (Social- og Indenrigsministeriet 2019) sammenlignet med langvarige eller permanente indsatser. Særligt på socialområdet har erfaringerne vist, at tværgående og helhedsorienterede indsatser ofte er meget velfungerende. Dette har medført en forøget interesse for økonomistyring i relation til både rehabiliteringsindsatser (f.eks. Dalsgaard et al. 2020) og helhedsorienterede forløb (Kjærgaard et al. 2018). I sådanne situationer har erfaringer især vist, at effektbaseret økonomistyring (Bukh \& Christensen 2018a, 2020) kan være en egnet måde at udvikle den økonomiske styring på, idet der her fokuseres på sammenhængende indsatser og på de muligheder, ressourcetildelingen giver for at skabe gode resultater.

\section{2. Økonomistyringen konstruerer ledelsesrummet}

Ledelsesrummet handler om, hvilke beslutninger en leder kan træffe, hvilke konsekvenser af beslutninger og aktiviteter lederen har ansvar for, samt hvordan beslutningerne og konsekvenserne påvirker budgetter og regnskaber. Som ledelsesredskab er økonomistyring med til at konstruere ledelsesrummets rammer. Det gælder særdeles, når der anvendes tildelingsmodeller baseret på eksplicitte finansieringsformler (Bukh \& Christensen 2020; Mayston 1998; Smith 2007), der bestemmer budgetterne for decentrale enheder som f.eks. hjemmeplejeteams, skoler eller botilbud.

Den effektbaserede styring tager udgangspunkt $\mathrm{i}$, at det decentrale ledelsesrum skal styrkes for at skabe mere værdi for borgerne (Bukh \& Christensen 2020; Christensen \& Bukh 2018). Dette hviler på en præmis om, at en decentral og lokal ledelse må forventes at have en bedre forståelse for den lokale efterspørgsel efter serviceydelser, samt hvordan denne service mest omkostningseffektivt kan leveres, sammenlignet med en central ledelse, der organisatorisk såvel som fysisk er placeret længere væk. Dermed bliver decentralisering af beslutningskompetence og økonomisk ansvar afgørende i forhold til borgeren og kerneopgaven.

Decentralisering indebærer, at både politikerne og den centrale myndighed - ofte betegnet bestilleren eller betaleren - skal afgive beslutningskompetence til udførerne. Når denne decentralisering sker ved en tildelingsmodel, bliver modellens evne til ex ante at omsætte betalerens målsætninger til økonomiske mål afgørende for, hvordan udføreren handler ex post. Hvis modellen tildeler ressourcer efter, hvilke aktiviteter der udføres, skabes en stærk kobling mellem betalerens præferencer for aktiviteter, mens prioriteringen mellem effektmål er delegeret til udføreren. Hvis der derimod indgår effektmål i betalingsformlen, skabes der en stærk kobling af betalerens præferencer for bestemte effekter mens beslutningerne om, hvordan effekten opnås, er delegeret til udføreren. 
Denne decentralisering omfatter ikke blot den formelle bevillingsafgivelse, når kommunalbestyrelsen placerer den økonomiske beslutningskompetence hos f.eks. embedsmænd eller institutioner (Heeager 2017), men kan også omfatte den reelle fordeling af ressourcer fra forvaltningen til de enkelte aktiviteter eller tilbud inden for bevillingsområdet. Det kan der være ulemper ved, men det opfattes normalt som den pris, der må betales for at forbedre de decentrale beslutninger (Smith 2007, p. 19). Imidlertid kan decentraliseringen eller opgavedelegering skabe nye styringsproblemer (Jacobsen \& Jakobsen 2014; jf. Heeager 2017). Det sker både, fordi sammenhængen mellem målsætninger og mål er ukomplet (Mouritsen 2018), og fordi der ikke er sikkerhed for, at den decentrale leder faktisk er motiveret til at forfølge de mål, som betalingsformlen angiver, med den ønskede intensitet og vedholdenhed.

\section{Artiklens formål og opbygning}

I denne artikel tager vi udgangspunkt i, at tildelingsmodeller ikke blot er instrumenter til fastlæggelse af budgetter, men at de også udgør en incitamentsstruktur, hvor decentrale enheder motiveres til at forfølge de mål, som tildelingsmodellen er baseret på, og tilsvarende motiveres til at nedprioritere mål, der ikke indgår i tildelingsmodellen. Vi argumenterer derfor for, at man eksplicit skal analysere, om tildelingsmodeller indeholder de ønskede incitamenter.

Tildelingsmodeller udgør grundlaget for både ressourcetildeling og den interne budgetlægning i store dele af den offentlige sektor. Ved bedre at forstå teknikkerne bag konstruktionen af sådanne modeller kan fordele og ulemper ved forskellige modeller identificeres og analyseres. I artiklen vil vi vise, hvordan forskellige produktionsstrukturer kendetegner den offentlige sektor. I forlængelse heraf vil vi diskutere, hvilke krav disse produktionsstrukturer stiller til designet af en effektbaseret økonomistyringsmodel i relation til at konstruere et velfungerende ledelsesrum. Vi har i denne artikel særligt fokus på den form for budget- og tildelingsmodeller, som anvendes på psykiatri- og handicapområdet samt ældreområdet i kommunerne. Men tilsvarende modeller anvendes eksempelvis på folkeskoleområdet, i sundhedssektoren og i selvejende uddannelsesinstitutioner.

Artiklen er struktureret således, at vi i afsnit B først beskriver, hvordan en virksomheds økonomistruktur er sammensat af dens produktions- og omsætningsstruktur. Desuden introducerer vi en skelnen mellem to særlige produktionsstrukturer i form af forløbs- henholdsvis periodebaserede indsatser. I afsnit C diskuterer vi tildelingsmodellers incitamenter, hvorefter principperne bag effektbaserede tildelingsmodeller præsenteres i afsnit D. Med afsæt i konkrete eksempler viser vi i afsnit E, hvordan en effektbaseret tildelingsmodel kan konstrueres for forløb, mens vi i afsnit $\mathrm{F}$ viser, hvordan effektbaserede økonomistyringsmodeller kan udvikles for periodebaserede indsatser. Artiklen afrundes i afsnit G. 


\section{B. Økonomistrukturens betydning}

Situationsbetingede økonomistyringsteorier (Mouritsen 1987) bidrager med generel indsigt i, hvordan behovet og mulighederne for anvendelse af bestemte økonomistyringsteknikker påvirkes af f.eks. omgivelsesusikkerhed, virksomhedsstørrelse eller produktionsteknologi. På et generelt plan drejer teknologi sig om, hvordan arbejdsprocesserne fungerer, dvs. den måde input transformeres til output ved anvendelse af maskiner, værktøjer, materialer, medarbejdere, software og viden (Chenhall 2007, p. 174). Inden for økonomistyringslitteraturen har teknologiens betydning for økonomistyringsdesign især været studeret med udgangspunkt i organisationens kompleksitet, opgaveusikkerhed og koordinationsbehov (Chenhall 2007).

Teknologi er også et spørgsmål om, hvilke principper der ligger til grund for produktionens organisering. Når sådanne situationsbetingede forhold varierer virksomheder imellem, er det bl.a., fordi de producerer forskellige produkter (eller serviceydelser), samt fordi der er fordele ved at organisere produktionen af bestemte produkter på en given måde. Det indebærer, at en virksomheds produkttyper og dermed dens branche har indflydelse på, hvordan der skal styres i den enkelte virksomhed. I et pengeinstitut vil der f.eks. være behov for at kunne lave kunde- og filiallønsomhedsanalyser, der tager højde for forventede kredittab og -nedskrivninger samt at inddrage en allokering af egenkapital på kundeniveau i disse kalkulationer. Tilsvarende modeller vil ikke på samme måde være relevante i en produktionsvirksomhed, uanset hvilken størrelse den har.

\section{Produktions- og omsætningsstruktur}

Produktionsstrukturen afspejler den måde, det er besluttet at udføre produktionen, eller mere generelt udførelsen af arbejdsopgaverne, på. Vi betoner, at der er tale om et valg fremfor, at produktionsstrukturen er betinget af f.eks. branchen eller, hvad der produceres. I nogle situationer vil produktionsstrukturen nærmest være givet på forhånd, f.eks. vil det være ordreproduktion, hvis et polargående ekspeditionsskib bygges på baggrund af en specifik kundeordre. I andre situationer vil der være valgmuligheder, f.eks. kan en bil produceres som enkelt-styk ordreproduktion, som serieproduktion, eller ved en Lean-produktionsstruktur (enkelt-styks masseproduktion).

På samme vis er der forskel på den måde, virksomheder afsætter sine produkter og prissætter dem. Dette vil vi betegne virksomhedens omsatningsstruktur. I nogle situationer vil omsætningsstrukturen være markedsbestemt, f.eks. sælges en liter mælk oftest til en udbudt pris på nogenlunde samme måde alle steder i detailhandlen. I andre situationer vil virksomheden kunne vælge helt forskellige omsætningsstrukturer, der afspejler forskellige forretningsmodeller. For eksempel kan film sælges i en butik ligesom mælk, men den kan også afsættes via andre distributionskanaler, f.eks. on-demand streaming eller abonnementsbaseret, mens det er vanskeligere at forestille sig, at mælk kan sælges abonnementsbaseret. 
Tilsammen udgør produktions- og omsætningsstruktur virksomhedens økonomistruktur, idet denne anvendes som "et udtryk for de stabile relationer mellem omsætning, omkostninger, salg og produktion" (Mouritsen 1987, p. 29). Dermed er økonomistrukturen et billede af de fysiske sammenhænge i virksomhedens produktion og salg, således at styringsopgaverne, som beskrevet af Mouritsen (1987), er udtryk for de ledelsesopgaver, der kan kobles til styringen af produktion og salg. Denne sammenhæng er illustreret ved figur 1, som viser, at virksomhedens strategi bestemmer dens forretningsmodel, som udtrykkes ved en valgt produktions- og omsætningsstruktur, som økonomistyringen skal passe til.

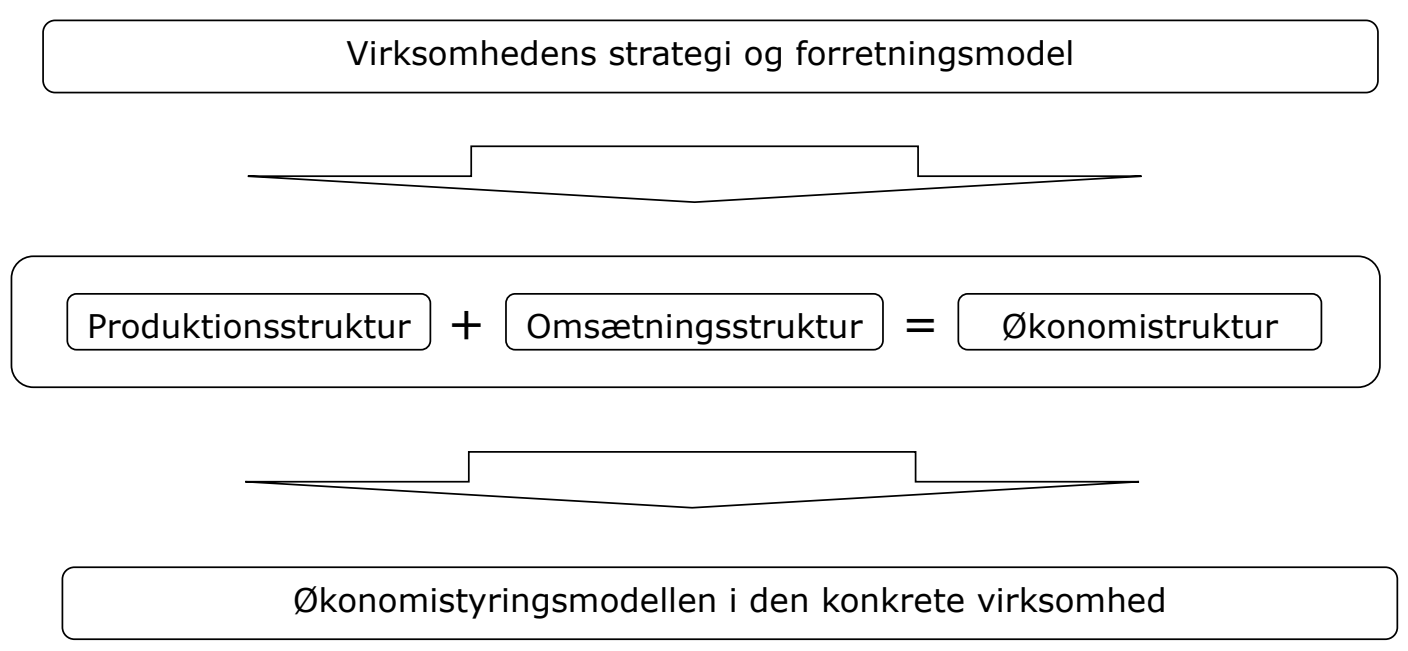

Figur 1: Strategi, økonomistruktur og økonomistyringsmodel

I private produktionsvirksomheder vil man ofte skelne mellem forskellige typer af økonomistyring, der er særligt anvendelig afhængig af økonomistrukturen og dermed af omsætnings- og produktionsstrukturen. Typisk opdeles i ordreproducerende, masseproducerende og serieproducerende virksomheder, men opdelingen kan forfines yderligere, således at der eksempelvis kan identificeres en særlig produktionsstruktur for f.eks. projektbaserede virksomheder (som er en variant af ordreproduktion). Når forskellige former for økonomistyringsmodeller beskrives i relation til de nævnte virksomhedstyper, vil det ofte være en underforstået præmis, at der i en branche er en typisk måde at producere og sælge på, hvilket betyder, at der vil være en typisk økonomistruktur, hvor en bestemt form for økonomistyring vil være hensigtsmæssig. Da virksomheder i den samme branche kan have forskellige strategier og forretningsmodeller, vil der i praksis ikke være én bestemt produktionsstruktur og én bestemt omsætningsstruktur, der altid anvendes i en branche. Både produktions- og omsætningsstrukturen udgør et strategisk valg, som er en del af den enkelte virksomheds forretningsmodel. Dette er illustreret ved den øverste del af figur 1. 


\section{Har det offentlige ejeskab en betydning?}

Denne artikel har fokus på anvendelsen af tildelingsmodeller i den offentlige sektor, men det er vigtigt at slå fast, at ejerskabet ikke har betydning for valg af produktionsstrukturer. En offentlig virksomhed, der har samme økonomistruktur som en privat produktionsvirksomhed, vil med fordel kunne anvende fuldstændigt samme økonomistyringsprincipper. De klassiske økonomistrukturer, der ofte anvendes som eksempler i økonomstyringslærebøger, baserer sig dog ofte på (salgs- og) produktionsstrukturer, der forudsætter en mere eller mindre traditionel fysisk produktion. Der er imidlertid ikke så mange offentlige virksomheder, der oplagt kan karakteriseres som produktionsvirksomheder, og sædvanligvis opfattes produktion som opgaver, der bedst varetages af det private erhvervsliv. ${ }^{\text {ii }}$

Derudover er der situationer, hvor offentlige virksomheder som følge af lovgivning, regler og politiske beslutninger er begrænsede i de opgaver, de kan løse, samt i deres strategiske muligheder for at vælge produktionsstruktur og udvikle nye forretningsmodeller, der indebærer andre omsætningsmodeller. Eksempelvis kan det i lovgivningen være fastlagt, hvordan offentlige virksomheder skal beregne omkostninger, og hvordan takster (dvs. priser) skal fastlægges etc. Men private virksomheder er også underlagt begrænsninger, og fælles for de private og offentlige virksomheder er, at begrænsninger og muligheder afspejler valg, der er truffet fremfor, at de er konsekvenser af ejerskabet.

Det er dog også sådan, at der er visse typer "produktion", der i Danmark primært findes i den offentlige sektor, og som ofte også er offentligt finansieret. Det gælder både ældre- og sundhedsområdet samt de specialiserede indsatser på både voksen- samt børne- og ungeområdet. Eksempler omfatter skoleundervisning, som primært finder sted i folkeskolen, men hvor privat- og friskoler tilbyder tilsvarende produkter. Det samme gælder voksenundervisning, som kan udbydes af både private kursusvirksomheder og af selvejende uddannelsesinstitutioner. Ligesom hjemmepleje også kan leveres af private virksomheder, og mange botilbud på social- og handicapområdet er privatejede.

Selvom der findes private virksomheder, der leverer fuldstændig de samme tilbud, er økonomistyringen i en offentlig virksomhed karakteriseret ved, at der skal tages en lang række andre hensyn. F.eks. er budgetoverholdelse i kommuner og regioner særlig vigtig på grund af budgetloven og de statslige sanktioner, som træder i kraft, hvis budgetterne overskrides ${ }^{\text {iiiiv }}$. Desuden påvirker specifik faglovgivning (f.eks. serviceloven, socialtilsynsloven og retssikkerhedsloven) og supplerende styringselementer (f.eks. udredningsret og frit sygehusvalg) handlefriheden og dermed ledelsesrummet. Hertil kommer, at der ofte er særlige hensyn til, at der skal være en vis lighed i tildelingsprincipperne (jf. Bukh \& Christensen 2020). 
Endelig har kommuner og regioner en særlig periodiseringsudfordring, som dels skyldes, at budgetter og regnskaber reelt er udgiftsbaserede fremfor omkostningsbaserede, og dels at budgetloven og sanktionsstyringen fastlægger årlige udgiftsrammer for serviceudgifter og investeringer (dvs. anlæg). I forlængelse heraf er det desuden en væsentlig praktisk udfordring, at der ikke kan foretages investeringer i driftsforbedringer eller aktiver finansieret ved at reducere overskuddet det enkelte år med henblik på at skabe større rentabilitet i følgende perioder, ligesom der er begrænsninger for adgangen til at lånefinansiere investeringer. ${ }^{v 4}$ Disse forhold betyder, at der både i kommuner og regioner er et stort behov for at kunne styre, f.eks. hvordan øgede udgifter til indsatser på et tidspunkt og forbedret omkostningseffektivitet på et andet tidspunkt påvirker budgetoverholdelsen i forskellige perioder.

\section{Eksempel: Undervisning}

Fjerner vi blikket fra de traditionelle produktionsvirksomheder, kan der identificeres andre former for produktionsstrukturer. F.eks. udgør undervisning, som det praktiseres på stort set alle skoler og uddannelsesinstitutioner i Danmark, en særlig produktionsstruktur, der har lighedstræk med serieproduktion, men som alligevel er ganske anderledes. Både offentlige og private universiteter, gymnasier og grundskoler kan dog styres og ledes på den samme måde, ligesom der som udgangspunkt heller ikke er forskelle på efter- og videreuddannelse på et universitet og private kursusvirksomheder. Det er som udgangspunkt ikke et spørgsmål om privat eller offentligt ejerskab eller om privat eller offentlig finansiering af aktiviteterne.

Produktionsstrukturen for undervisning er i særdeleshed karakteriseret ved, at der er relativt høje kapacitetsomkostninger kombineret med, at disse er sambestemte i forhold til de aktiviteter, der indgår i en hierarkisk aktivitetsstruktur (Bukh \& Israelsen 2004, afsnit 3.4.2). Dette betyder, at der omkostninger, der er direkte i forhold til den enkelte undervisningslektion (underviserens tilstedeværelse og lokalet), mens andre omkostninger vedrører aktiviteter, der er direkte i forhold til det enkelte hold (oprettelse af holdet på læringsplatform, tilrettelæggelsen af eksamen etc.) eller den enkelte uddannelse (markedsføring, vedligeholdelse af studieordning etc.). Endelig er omkostningerne til forberedelse sambestemte i forhold til afviklingen af de enkelte lektioner, hvilket indebærer, at enhedsomkostningerne ved en lektion er væsentligt lavere, når den samme lektion kan gentages på flere hold. Disse karakteristika betyder, at der er potentiale for stordriftsfordele på alle niveauer: Udbydes flere uddannelser eller kurser er det mere effektivt end få, har man flere studerende på et hold, falder gennemsnitsomkosningerne etc.

Dykker vi lidt dybere ned i undervisningsproduktionen, kan der identificeres varianter, der ikke blot afhænger af, hvor mange der deltager i undervisningen, men også af en række valg, der ikke alene er bestemt af pædagogiske hensyn, men også afspejler strategiske valg og forskelle i forretningsmodeller. Der er således forskelle på, hvorvidt der anvendes forelæsninger eller 
holdbaseret øvelsesundervisning, ligesom der også er forhold, der er anderledes i forhold til vejledning af eksempelvis studiegrupper og ph.d.-studerende. Ligeledes indebærer forskellige strategier og forretningsmodeller, at undervisningsvirksomheder vælger forskellige omsætningsstrukturer. Eksempelvis kan undervisning ikke blot være studier på f.eks. videregående uddannelsesinstitutioner eller enkeltstående kurser udbudt af kursusvirksomheder, men undervisning kan også afsættes online uden en egentlig fysisk interaktion med en underviser, ligesom undervisning kan afsættes abonnementsbaseret. Sammenfattende giver disse valg af produktionsstruktur og omsætningsstruktur anledning til forskellige økonomistrukturer, som har betydning for, hvordan virksomhedens økonomistyring kan og bør tilrettelægges.

\section{Forløbsbaserede eller periodebaserede indsatser}

Udover undervisning, som vi i det foregående afsnit brugte som eksempel, kan der identificeres andre produktions- og økonomistrukturer, der er særligt relevante eller udbredte i den offentlige sektor. Igen er det ikke det offentlige ejerskab, der bestemmer produktionsstrukturerne. Et eksempel er "beredskab", der udover alarmcentraler og udrykning også omfatter f.eks. akutmodtag (skadestuer) og borgerservice. Tilsvarende kunne det måske være relevant at identificere særlige økonomistrukturer for museer, koncerter, events etc. I denne artikel har vi dog særligt fokus på psykiatri- og handicapområdet samt ældreområdet i kommunerne, hvor det er vores erfaring, at det er vigtigt at skelne mellem to forskellige produktionsstrukturer for ydelser og tilbud, rettet mod de enkelte borgere: forløbsbaserede henholdsvis periodebaserede indsatser.

Ved forløbsbaserede indsatser forstår vi midlertidige indsatser, hvilket omfatter forskellige former for indsatser, der som udgangspunkt er enkeltstående eller tidsafgrænsede. Det kan f.eks. være en knæoperation i sundhedsvæsnet eller genoptræning efter hospitalsindlæggelse. I kommunalt regi kan det være et kort intensivt rehabiliteringsforløb på ældreområdet, misbrugsafvænning eller en sprogindsats i dagtilbud, ligesom en del arbejdsmarkedsindsatser også falder i denne kategori. Det midlertidige betyder ikke, at afdelingen, der leverer ydelser, er midlertidig, og det tidsafgrænsende betyder ikke, at aktiviteten skal vedrøre bestemte budgetmåneder eller -år. Forløb skal blot opfattes som afgrænsede og midlertidige indsatser, der ikke er permanente, selvom forløb kan forlænges eller gentages. Til forskel herfra anvender vi begrebet periodebaserede indsatser om længerevarende eller ligefrem 'permanente' aktiviteter. Disse omfatter dels aktiviteter som undervisnings- og børnepasningstilbud, der sædvanligvis strækker sig over flere år, men dog ophører på et tidspunkt, og dels aktiviteter, der er mere eller mindre permanente, medmindre der opstår en særlig forbedring i borgerens situation. Eksempler herpå omfatter botilbud på handicapområdet, plejecentre, hjemmepleje på ældreområdet samt forskellige kroniske sygdomme i sundhedsvæsnet. 
Med opdelingen i forløbs- og periodebaserede indsatser postulerer vi ikke en bestemt måde, hvorpå f.eks. socialfaglige indsatser eller inklusion i folkeskolen skal forstås. Ligeledes kan afgrænsningen mellem de to typer indsatser mere være et spørgsmål om skøn og begrebsdefinition end reelle forskelle, og nogle midlertidige indsatser kan i praksis være forholdsvis langvarige, ligesom permanente indsatser i praksis kan overgå til at være midlertidige eller være kortvarige. Ved kommuners arbejde med effektbaseret styring på de kommunale serviceområder har denne skelnen mellem forløbs- og periodebaserede indsatser dog vist sig at være praktisk (se f.eks. Odense Kommune 2014). Efter en nærmere vurdering af danske erfaringer fra praksis såvel som $\mathrm{i}$ litteraturen har en arbejdsgruppe nedsat af Styregruppen for Værdibaseret Styring på tilsvarende vis konkluderet, at der kan skelnes mellem behandling af patienter med kroniske sygdomme, elektiv behandling, behandling af akutte funktioner samt behandling i højtspecialiseret regi (Danske Regioner 2016).

Denne identifikation af forskellige typer produktionsstrukturer er formodentlig forholdsvis generel på tværs af hele den offentlige sektors aktiviteter, hvilket er væsentligt, idet bestemte former for økonomistyring er særligt egnede i relation til bestemte produktionsstrukturer. Det betyder, at erfaringer med økonomistyring kan overføres mellem områder, der har samme produktionsstruktur, uanset hvilke faglige aktiviteter områderne vedrører. F.eks. vil man ved forløbsbaserede indsatser som tildelingsmodeller for korte, intensive rehabiliteringsforløb på ældreområdet (Jensen \& Olesen 2018a, 2018b) kunne hente inspiration fra de principper, der anvendes i den økonomiske styring på arbejdsmarkedsområdet i forbindelse med at få ledige i beskæftigelse. Ligeledes vil de samme styringsprincipper kunne anvendes inden for ortopædkirurgien (jf. Bjerregaard \& Christensen 2018) og stoffri misbrugsbehandling i kommunalt regi. Det er en væsentlig observation, der betyder, at man for at få inspiration til udvikling af nye økonomistyringsmodeller inden for f.eks. sundhedsområdet måske i højere grad bør hente inspiration fra, hvordan aktiviteter med tilsvarende produktionsstrukturer styres på andre områder i stedet for at forsøge at generalisere erfaringer fra styringen på enkelte behandlingsområder til en mere generel styringsmodel for hele sundhedsvæsnet.

\section{Tildelingsmodellers motiverende betydning}

Ordet motivation har en latinsk oprindelse, idet movere betyder at bevæge eller flytte. Derfor indebærer motivation en tilbøjelighed til at bevæge sig eller handle. Hvis en person ikke ønsker at gøre en bestemt ting, vil man i daglig tale opfatte personen som umotiveret, mens den, der har lyst til at gøre noget eller føler et behov for det, vil være motiveret. I begge tilfælde er motivation ikke udtryk for en øjeblikkelig sindsstemning, men en tilbøjelighed til at handle i forhold til et mål. Altså en målrettethed. Ud fra dette perspektiv handler motivationsteori om, hvilke behov mennesker har, 
samt hvordan disse behov tilfredsstilles; og graden af motivation er derfor et spørgsmål om de behov og incitamenter, dvs. de positive og negative udfald, som handlinger i en given situation kan resultere $\mathrm{i}^{\mathrm{ri}}$

Vi motiveres af mange forskellige ting med hver sine incitamenter tilknyttet. Det er almindeligt at tage udgangspunkt $\mathrm{i}$, at medarbejdere motiveres af at udføre deres arbejde bedst muligt, samt at medarbejdere i den offentlige sektor i høj grad ønsker at bidrage til gavn for borgerne og samfundet i det hele taget (Andersen \& Pedersen 2014). På universiteterne vil vi eksempelvis gerne skrive gode artikler, som mange læser har nytte af, ligesom vi gerne vil uddanne studerende, der er dygtige til deres fag, får et arbejde og oplever et personligt udbytte af deres uddannelse. Læger ønsker at behandle deres patienter og sikre dem en god livskvalitet, og sagsbehandlere vil gerne afgøre sagerne korrekt, overholde loven og sikre, at borgerne bliver godt informeret om deres rettigheder.

\section{Tildelingsmodeller og incitamenter}

Den gode vilje og det faglige engagement skal naturligvis fungere, samtidig med at der både er mange andre hensyn, der skal afbalanceres i forhold til hinanden, og at mange interessenter har legitime holdninger til, hvad der kendetegner godt arbejde i den offentlige sektor. Det kræver prioriteringer, og når de økonomiske ressourcer ikke er ubegrænsede, skal der også foretages en prioritering af hvilke økonomiske ressourcer, der skal bruges på de enkelte områder. Det er én af årsagerne til, at der er brug for nogle principper for, hvordan enkelte hospitalsafdelinger, skoler, universiteter osv. tildeles økonomiske ressourcer. Når disse ressourcer fordeles ved anvendelse af en økonomistyringsmodel, er der tale om en tildelingsmodel (Bukh \& Christensen 2020). Alternativt kunne fordelingen af ressourcerne ske ved f.eks. en politisk forhandling, herunder politiske byttehandler, eller være fastlagt som en videreførelse af sidste års budget (Smith 2007, afsnit 1.5), eventuelt med et fast procentuelt sparekrav.

Hvad enten man er bevidst om det eller ej, er enhver tildelingsmodel også en incitamentsmodel (jf. Bech 2008). Derfor vil medarbejderne i en offentlig virksomhed motiveres til at lægge vægt på de kriterier, som virksomheden tildeles økonomiske ressourcer efter, og de kriterier, virksomheden ikke tildeles for, får modsat mindre fokus. Det giver anledning til en række dilemmaer, hvor styringen kan skabe et utilsigtet spændingsfelt mellem de faglige hensyn og budgetmodellens implicitte incitamenter. Hvis der f.eks. gives bevillinger efter antallet af dage en indsats varer, kan man så forvente, at medarbejderne har fuldt fokus på at effektivisere indsatsen og nedbringe varigheden? Hvis der tildeleles ressourcer efter antallet af ydelser, kan man så forvente, at de afdelinger, der modtager bevillingerne, har fokus på at arbejde rehabiliterende og derved reducere antallet af ydelser? Tildelingsmodellerne påvirker ikke blot de muligheder, ledere og medarbejdere har for at handle, men også deres holdninger. Derfor er designet af tildelingsmodellen et afgørende omdrejningspunkt for, hvilke resultater der opnås i den offentlige sektor 
Tildelingsmodellerne skaber, bevidst eller ubevidst, en incitamentsstruktur, der ikke blot giver tilskyndelser til at handle. De påvirker også medarbejdernes holdninger og opfattelser af den økonomiske styring og skaber nye meninger (Bukh et al. 2020a, 2020b). Mere direkte konstruerer tildelingsmodellerne også et specifikt ledelsesrum (Bukh \& Christensen 2018a; 2020), fordi de angiver, hvilke beslutninger, konsekvenser af beslutninger og aktiviteter man har ansvar for, og fordi de bestemmer, hvordan beslutninger påvirker de økonomiske rammer.

Hvis antallet af borgere, der er visiteret til en indsats, er et tildelingskriterie, og hvis der anvendes en fast takst pr. borger, så indebærer tildelingsmodellen incitamenter til både at fortsætte med indsatsen og ydermere at visitere flere borgere til indsatsen. Jo mere selvhjulpen borgeren er, jo færre ressourcer bruges på indsatsen i forhold til taksten, og desto stærkere bliver incitamentet til at fortsætte indsatsen eller med andre ord ikke at 'afslutte borgeren'. Den daværende direktør i Fldre- og Handicapforvaltningen i Odense Kommune, Helene Bækmark, udtalte eksempelvis i et interview, at:

Man kan jo ikke have rehabiliteringsforløb, hvor vi sender borgeren ud i livet igen og samtidig beholde en økonomistyringsmodel, der gør, at man som leder bliver straffet i form af mindre budgetter og opsigelse af personale, hvis man er dygtig til at sende borgeren ud i livet igen

(Ekeroth 2014)

Tilsvarende gælder for en folkeskole: Hvis tildelingsmodellen f.eks. indeholder en takst pr. elev, tilskyndes man til at indskole mange elever, men hvis den indeholder en takst pr. klasse, tilskyndes man til at oprette klasser fremfor at fylde de klasser op, man allerede har. Ligeledes hvis tildelingsmodellen indeholder en betaling fra skole til specialskole for specialundervisning, tilskyndes man til at inkludere elever. Disse eksempler er alene nøgterne vurderinger af, hvordan tildelingsprincipperne determinerer en incitamentsstruktur, som motiverer til at forfølge specifikke mål. Hvorvidt disse mål er hensigtsmæssige, de vigtigste mål, eller hvordan de skal afvejes i forhold til andre mål, er en politisk og ledelsesmæssig beslutning. Som vi i en tidligere artikel (Bukh \& Christensen 2020) har pointeret, så er tildelingsmodeller ikke neutrale redskaber, fordi de effekter, de fremmer, ikke er neutrale, men afspejler bestemte politiske og ledelsesmæssige værdier og mål.

\section{Incitamenter til effekt}

De økonomiske incitamenter i tildelingsmodeller indgår i et kompliceret samspil med andre incitamenter, og de påvirker motivation og adfærd på mange måder. I den nationale debat om ledelse og styring i den offentlige sektor har kontrol og detailstyringspåvirkning af de ansattes indre 
motivation fået en del opmærksomhed (Andersen et al. 2017; Andersen \& Pedersen 2014; Produktivitetskommissionen 2013). Andersen et al. (2017, p. 146) konkluderer eksempelvis, at økonomiske incitamenter kan have en negativ motivationseffekt, hvis de opfattes som værende i modstrid med faglige opfattelser af, hvad de rigtige indsatser bør være - og omvendt en positiv motivationseffekt, når de opfattes som understøttende for arbejdet, og når styringen er i overensstemmelse med fagprofessionelle normer.

Det er naturligvis ikke en ny erkendelse, at der skal tages højde for incitamentsstrukturen (se f.eks. Smith 2007, p. 120). Bech \& Pedersen (2006, p. 147) slog med henvisning til Frey (1997) fast, at optimal incitamentsstyring "er at bruge de typer af økonomiske og ikke-økonomiske incitamenter, som bidrager mest til medarbejdernes motivation", og Produktivitetskommissionen (2013, p. 17) pegede på, at:

De gældende finansieringssystemer kan undertiden hæmme samarbejdet mellem fx kommuner og regioner om sammenhængende opgaveløsninger med udgangspunkt i borgernes behov. Det sker, hvis den enkelte enhed har fokus på sit eget ressourceforbrug frem for de samlede ressourcer, der bliver brugt i forløbet. Den aktivitetsbaserede takstfinansiering kan også give et utilsigtet incitament til at nedprioritere hensynet til kvalitet i opgaveløsningen, hvis afregningen ikke tager hensyn til kvaliteten i ydelsen.

Det er derfor vigtigt at være opmærksom på, hvilken betydning den implicitte incitamentsstruktur har i tildelingsmodellen. Men det er mindst lige så væsentligt, hvad tildelingsmodellen ikke indeholder incitamenter til: Hvis det væsentligste tildelingskriterie er antallet af indlæggelser på et hospital, kan man så forvente, at der i fuldt omfang arbejdes på at reducere antallet af indlæggelser? Hvis universiteter primært tildeles ressourcer efter, hvor mange eksamener studerende består, kan man så regne med, at der undervises og eksamineres på et tilstrækkeligt højt niveau?

Der kan også ligefrem være tale om, at tildelingskriterierne uforvarende er i modstrid med de politisk fastlagte mål, eller det som faktisk er bedst for borgeren: Hvis børnene i daginstitutionerne skal være skoleparate og starte i 0 . klasse, når de er i den skolepligtige alder, hvorfor tildeler man så yderligere ressourcer til daginstitutionerne, når børnenes skolegang udsættes? Det gøres der naturligvis, fordi der er udgifter forbundet med, at børnene er i børnehaven et år ekstra, men det har også den implicitte konsekvens, at børnehaven ikke tildeles ressourcer, hvis børnene starter i skolen, og der er en tom plads i børnehaven.

Løsningen, som nogle kommuner vælger, er helt enkelt at basere tildelingen til børnehaverne på, at en given andel af børnene får udskudt deres skolestart, således at tildelingen pr. måned i en "normal" børnehaveperiode er højere og tilsvarende lavere (f.eks. på samme niveau som udgifterne 
i en SFO) ved udskudt skolestart. I den mest vidtgående version sættes børnehavetaksten til 0 kr., hvis børnene forbliver i børnehaven fremfor at starte i skolen. Da taksten i den 'normale' børnehaveperiode er højere, vil en del af den kommunale besparelse ved at undgå skoleudsættelse tilfalde børnehaven, hvor ressourcerne eksempelvis vil kunne anvendes til pædagogiske aktiviteter.

Tilsvarende: Hvis det for bestemte målgrupper besluttes, at patienterne så vidt muligt skal behandles i eget hjem, hvorfor så tildele hospitalerne ressourcer efter, hvor mange gange borgeren indkaldes til ambulante aktiviteter? Spørgsmålet afspejler den ofte diskuterede problemstilling forbundet med at styre hospitalsafdelinger efter produktionsvolumen fremfor den værdi, det skaber for patienterne. Løsningen kan være helt at fjerne den takstafhængige betaling og tildele faste budgetter eller budgetter baseret på kapitafinansiering ${ }^{\text {vii. }}$ Men der kan også være tale om at ændre takststrukturen, så den i højere grad bliver baseret på hele patientforløb og en form for 'bundled payment' (Herzlinger \& Huang 2014; Porter \& Kaplan 2016) fremfor at afregne episodebaseret som i en traditionel DRG-model.

Når økonomer giver eksempler som ovenfor, kan det fremstå, som om vi mistænker dygtige fagfolk for at spekulere i at maksimere deres budgettildeling fremfor at gøre det rigtige for borgerne. Det er ikke vores ærinde her. Vi vil i stedet påpege og argumentere for, at effektbaserede tildelingsmodeller skal være kendetegnet ved, at de så vidt muligt ikke er i modstrid med det, man ønsker at opnå, og at de så vidt muligt tildeler ressourcer i overensstemmelse med den effekt, der ønskes. Derfor opfatter vi tildelingsmodeller med indbyggede incitamenter til at øge omkostningseffektiviteten som udtryk for en tillidsbaseret styringsform, hvor det decentrale ledelsesrum øges, så ansvaret for effekten, mulighederne for at handle og de tildelingsmæssige konsekvenser synkroniseres. Dette er både et spørgsmål om at reducere incitamenterne til at gøre det uhensigtsmæssige og om at øge incitamenterne til at gøre det, som er fagligt fornuftigt såvel som politisk prioriteret. Kerr (1975) påpegede i en klassisk artikel "the folly of rewarding A while hoping for B”, hvilket i al sin enkelthed er en god påmindelse, når tildelingsmodeller tilrettelægges.

\section{Effektbaserede tildelingsmodeller}

Tildelingsmodeller indebærer en finansieringsmodel, hvor en budgetenhed tildeles ressources ud fra en på forhånd fastlagt finansieringsformel. Denne formel består typisk af tre komponenter: En fast budgettildeling $\left(F_{i}\right)$, en takstafhængig tildeling $\left(T_{i}\right)$ samt en såkaldt kapitatildeling $\left(K_{i}\right)$, sidstnævnte justerer budgettet for den relative udgiftstyngde (Bukh \& Christensen 2020; Smith 2007). Det betyder, at den samlede budgettildeling $\left(D_{i}\right)$ til distrikt $i$ bestemmes ved: $D_{i}=F_{i}+T_{i}+$ $K_{i}$. 
Tilføjer vi effekt som et kriterium, kan der skelnes mellem to former for effektbaserede tildelingsmodeller: indgår der direkte effektmål i tildelingskriterierne eller ej? En direkte effektbaseret tildelingsmodel betyder, at nogle af tildelingskriterierne er formuleret som effektmål fremfor input-, proces- og outputmål. Mens vi anvender begrebet indirekte effektbaseret tildeling, hvis modellen er baseret på økonomiske incitamenter, der er tilstrækkelige til at øge omkostningseffektiviteten, men hvor effektmål ikke indgår som en del af tildelingskriterierne.

Når der anvendes en direkte effektbaseret tildeling, er grundprincippet, at en del af tildelingen gøres afhængig af, hvilken effekt der opnås. Dette vil sædvanligvis betyde, at effekt indgår i forbindelse med en takstkomponent. Dermed vil den takstafhængige komponent af tildelingen til enhed $i$, udover den sædvanlige takstkomponent, $T_{i}$, bestå af en effektkomponent, $E_{i}$. Taksttildelingen (se også Bukh \& Christensen 2020, afsnit C) til område $i$ bliver dermed: $T_{i}+E_{i}=\sum t_{k} \times n_{k i}+\sum e_{k} \times E_{k i}$, hvor:

$t_{k}=$ taksten for takstkriterie $k$

$n_{k i}=$ antal takstenheder for kriterie $k$ i budgetområde $i$

$e_{k}=$ taksten knyttet til effektmål $k, o g$

$E_{k i}=$ effekten opnået af budgetområde $i$ for effektmål

\section{Omkostningseffektivitet}

Når der udvikles effektbaserede tildelingsmodeller, er det vigtigt at skelne mellem (a) udgifter til konkrete aktiviteter eller indsatser i en indsatsperiode og (b) udgifter i fremtidige perioder. Dette skyldes, at den fremtidige udgiftsudvikling netop er påvirket af aktiviteterne og dermed udgifterne i de tidligere perioder. Omkostningseffektivitet er et spørgsmål om at forbedre forholdet mellem de omkostninger udgifter, der afholdes i ét tidsrum, og den effekt der opnås i form af både højere kvalitet og omkostningsreduktioner i samme tidsrum eller fremtidige perioder. Effekt kan altså både være omkostningsniveau, som er fremtidige omkostninger relateret til den samme borger eller den samme målgruppe, og øvrige relevante effektmål (f.eks. generelle livskvalitetsmål og borgerspecifikke mål), som vi vil sammenfatte som kvalitetsforbedringer. Det afhænger af den specifikke målgruppe, hvilke fremtidige omkostninger der indgår i omkostningsniveauet, samt hvilken fremtidig periode det drejer sig om.

Hvis vi med udgangspunkt i de to produktionsstrukturer, der er skitseret i afsnit B.4, skelner mellem forløbs- og periodebaserede indsatser, kan vi formulere to forskellige varianter af omkostningseffektivitet. For forløbsbaserede indsatser kan man fokusere på forløbsomkostninger, og man kan definere omkostningseffektivitet som: 


$$
\text { Omkostningseffektivitet }=\frac{\text { effekt }}{\text { forløbsomkostninger }}=\frac{\text { omkostningssniveau }+ \text { kvalitetsforbedring }}{\text { forløbsomkostninger }}
$$

Forløbsomkostninger er dermed de omkostninger, der er forbundet med et specifikt og afgrænset forløb, f.eks. genoptræning efter en hospitalsindlæggelse. For periodebaserede indsatser kan omkostningseffektivitet tilsvarende defineres som:

$$
\text { Omkostningseffektivitet }=\frac{\text { effekt }}{\text { periodeomkostninger }}=\frac{\text { omkostningsniveau }+ \text { kvalitetsforbedring }}{\text { periodeomkostninger }}
$$

Periodeomkostninger skal her forstås som alle relevante omkostninger forbundet med en specifik borger eller målgruppe inden for en bestemt periode, f.eks. en måned eller et budgetår. De to versioner af omkostningseffektivitet afspejler to forskellige perspektiver på indsatserne, f.eks. hvad angår den måde, der visiteres til dem. Ud fra en periodebetragtning kan en myndighedsafdeling f.eks. beslutte, at en borger skal tilbydes hjemmehjælp og tilsvarende foretage en ny beslutning, når omfanget skal ændres eller helt ophøre. Ved en forløbsbetragtning træffes der typisk en myndighedsafgørelse, om forløbet skal gennemføres, men den nærmere tilrettelæggelse af forløbet og måske også varigheden heraf besluttes af den afdeling, der udfører aktiviteten.

Omkostningseffektivitet i forhold til periodeomkostninger anvendes typisk i situationer, hvor borgeren tildeles en mere eller mindre permanent ydelse, f.eks. bostøtte, hjemmehjælp eller botilbud, eller vedkommende i en længere men objektivt afgrænset periode modtager ydelser fra kommunen, f.eks. skoler og dagtilbud. Endelig anvendes forløbsomkostninger i tidsafgrænsede forløb, således som det beskrives af Jensen \& Olesen (2018b).

\section{Vægtning af effektmål}

Når vi formulerer omkostningseffektivitet som angivet ovenfor, indebærer det, at en del af omkostningseffektiviteten kan udtrykkes økonomisk. Det giver mulighed for at sammenholde omkostninger i én periode, f.eks. et budgetår, med omkostninger i efterfølgende perioder, således at der kan afholdes omkostninger ud fra en investeringstankegang. Mange offentlige organisationer har netop fokus på at udvikle nye løsninger, der både reducerer omkostningerne fremadrettet og samtidig er bedre for borgeren (se f.eks. Thorball 2018). Tilsvarende kan eksempelvis periodeomkostningerne i folkeskolen øges som følge af en inklusionsindsats, hvilket kan reducere behovet for senere omkostninger til specialundervisning, hvormed omkostningseffektiviteten forbedres. 
Som Jensen \& Olesen (2018b, figur 1) beskriver, kan der til styringsformål vælges en eksplicit vægtning, så økonomiske hensyn vægtes med en fast procentdel, $\lambda$, i forhold til øvrige hensyn sammenfattet som kvalitet ${ }^{\text {viii }}$

$$
\text { Omkostningseffektivitet }=\frac{\lambda}{100} \cdot \frac{\text { omkostningsniveau }}{\text { forløbsomkostninger }}+\frac{(100-\lambda)}{100} \cdot \frac{\text { kvalitetsforbedring }}{\text { forløbsomkostninger }}
$$

Det er en generel problemstilling, at der er behov for en vægtning, hvis der indgår flere effektmål i en tildelingsmodel, og man skal være opmærksom på konsekvenserne af det trade-off mellem de to typer effekt, der vælges med vægtningen. Nedprioriteringen af mål, der ikke indgår i styringsmodellen eller indgår med lav vægt, betegnes output distortion (Bevan \& Hood 2006) og kan opfattes som en form for dysfunktionel adfærd. For at reducere eller helt undgå sådanne resultater kan der anvendes supplerende betingelser i tildelingsmodellen, således som vi viser det nedenfor. I en tildelingsmodel vil der ofte indgå flere effektmål, og derfor vil der være behov for at vægte de enkelte effektmål i forhold til hinanden for at gøre tildelingen "contingent on delivering good outcomes" (Porter \& Kaplan 2016, p. 92). Dette behov for vægtning er ikke anderledes end i andre tildelingsmodeller, hvor der indgår flere forskellige tildelingskriterier, f.eks. antal elever, antal oprettede klasser etc. på folkeskoleområdet. Enhver vægtning bør dog give anledning til nøje overvejelser, idet den forudsætter, at der faktisk kan foretages en ex ante vægtning, ligesom en uhensigtsmæssig vægtning kan føre til prioriteringer, der ex post ikke er omkostningseffektive.

En fast vægtning kan også være problematisk, hvis det efterfølgende viser sig, at ét eller flere af de mål, der indgår, udvikler sig uventet negativt, idet vægtningen kan blive opfattet som en tilladelse til frit at prioritere målene i henhold til netop denne vægtning. Standardløsningen er at indføre supplerende betingelser i tildelingsmodellen. Hvis vi f.eks. ser på to effektmål $E_{1}$ og $E_{2}$, vil en sædvanlig sammenvejning med vægtene $\beta_{1} \circ \mathrm{og} \beta_{2}$ indebære, at den samlede effekt, $E_{s}$, udtrykkes som $E_{S}=\beta_{1} E_{1}+\beta_{2} E_{2}$. For at undgå en utilsigtet suboptimering af $E_{1}$, kan der i tildelingsmodellen indføres et krav om, at en minimumseffekt skal opnås for ét eller flere af effektmålene. Dette gøres ved at fastlægge:

$E_{3}=\left\{\begin{array}{l}0 \text { hvis } E_{1}<\text { minimumseffekt } \\ 1 \text { hvis } E_{1} \geq \text { minimumseffekt }\end{array}\right.$

Således formuleres effekten i stedet på denne måde: $E_{S}=\beta_{1} E_{1} E_{3}+\beta_{2} E_{2}$. I eksemplet er der anført et minimumskrav for $E_{1}$, og der kunne på tilsvarende vis indføres et minimumskrav for $E_{2}$.

I tildelingen kan der også blive stillet krav om, at en bestemt minimumsindsats skal gennemføres, f.eks. hvad angår ventetid eller gennemførelse af bestemte udredninger, således at der gives en bod, 
dvs. en negativ takst, hvis ikke minimumsindsatsen er gennemført. Endelig kan der også indføres en negativ vægtning ved klager, der får medhold, dårlig brugertilfredshed etc. ved at definere:

$E_{4}=\left\{\begin{array}{l}0 \text { hvis ingen klager og tilfredshed ok } \\ 1 \text { hvis klager eller dårlig tilfredshed }\end{array}\right.$

I dette tilfælde vil effekten således være $E_{S}=\beta_{1} E_{1}+\beta_{2} E_{2}+\beta_{4} E_{4}$, hvor $\beta_{4}$ er negativ - eller $E_{S}=\beta_{1} E_{1} E_{3}+$ $\beta_{2} E_{2}+\beta_{4} E_{4}$ hvis både kriteriet vedr. minimumsindsats og klager skal indgå.

Når resultatmål ikke er opgjort i samme enheder, er det ikke givet på forhånd, hvordan de skal vægtes, og der skal derfor findes en egnet løsning, hvis flere effektmål skal indgå i tildelingsmodellen samtidigt. I praksis vil det ske under hensyntagen til væsentligheden af effektmålene samt de relative omkostninger, der er forbundet med at forbedre dem. Eksemplerne ovenfor illustrerer, hvordan man ofte håndterer vægtningen i praksis, men der er mange andre muligheder for at variere incitamenterne.

\section{E. Forløbsbaserede modeller: erfaringer fra Odense Kommune}

For at illustrere principperne ved udviklingen af en forløbsbaseret tildelingsmodel tager vi i dette afsnit udgangspunkt i den model, der blev udviklet i Odense Kommunes Ældre- og Handicapforvaltning (ÆHF) med henblik på at give en effektafhængig forløbsbaseret tildeling til det tidsafgrænsede forløb "Træning som Hjælp" (TSH). I afsnittet viser vi altså ikke blot, hvordan en forløbsbaseret model kan tilrettelægges, men også hvordan der kan anvendes en direkte effektbaseret tildelingsmodel, dvs. at nogle af tildelingskriterierne er formuleret som effektmål (Bukh \& Christensen 2020). ${ }^{\text {ix }}$

Da ÆHF som den første forvaltning i Danmark indledte arbejdet med at udvikle effektbaserede økonomistyringsmodeller (Holmgaard 2014), var det et fællestræk for modellerne, at de blev baseret på tildelingsprincipper, der skulle fremme omkostningseffektivitet. Den økonomiske styring blev dermed funderet på, at tildelingsmodellerne så vidt muligt skulle designes, så effekt indgik som et tildelingskriterie. 

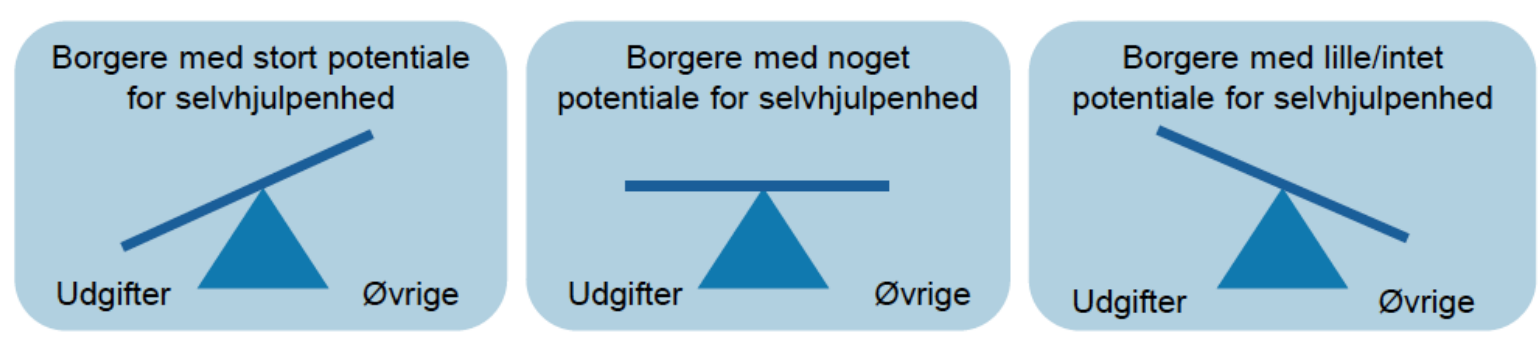

Figur 2: Det overordnede princip for effektafhoengige tildelingsmodeller i Aldre-og Handicapforvaltningen $i$ Odense Kommune (kilde: Jensen \& Olesen 2018b, p. 339).

I praksis blev det valgt, at udgiftsniveauet skulle vægte relativt højere i forløb, hvor der var stort potentiale for, at borgeren kunne opnå øget selvhjulpenhed, således som det er illustreret i den venstre del af figur 2, mens kvalitet (betegnet 'øvrige') tilsvarende vægtede relativt højere i forløb, hvor potentialet for selvhjulpenhed var mindre. Udtrykt som en relativ vægtning indebærer modellen vist i figur 2 , at udgiftsniveauet vægter med $\lambda=100 \%$ i den venstre side af figuren og tilsvarende $\lambda=0 \%$ i figuren til højre, mens den midterste figur illustrerer en vægtning mellem de to hensyn.

\section{TSH-forløbene}

TSH-forløbene var hverdagslivsrehabiliteringsforløb udviklet med inspiration fra den såkaldte Fredericia-model (Kjellberg et al. 2012), og de bestod af en kortvarig (8 uger) indsats rettet mod borgere, der havde et stort potentiale for selvhjulpenhed. Forløbene, der var tværfaglige, bestod af indsatser fra hjemmeplejen, sygeplejen samt træningsafdelingen. Omkring 70\% af udgifterne til forløbene vedrørte hjemmeplejeindsatser. TSH-forløbene er nærmere beskrevet af Kjellberg et al. (2012). Den forløbsbaserede tildelingsmodel blev inddraget af Hjemmehjælpskommissionen, der anbefalede, at tildelingsmodellen blev udbredt til andre kommuner. Se tekstboks 1.

"Kommissionen anbefaler, at kommunerne udvikler og arbejder med afregningsmodeller, der giver både private og offentlige leverandører et økonomisk incitament til at arbejde målrettet med en rehabiliterende indsats og forfølge øget kvalitet, målopfyldelse og effekt for borgerne... Nye økonomiske incitamentsstrukturer er således ifølge kommissionen en afgørende forudsætning for, at der kan arbejdes mere systematisk og målrettet med rehabilitering på ældreområdet... Det er desuden væsentligt at nævne, at ældreområdet i dag er kendetegnet ved ramme- eller aktivitetsbaseret styring. Det bør efter kommissionens opfattelse overvejes, om denne styringsform i større omfang, end det er tilfældet i dag, bør kombineres med en form for effektstyring, så bevillingerne i højere grad korrigeres for værdien af den kvalitet, som leveres.“

Tekstboks 1: Hjemmehjoelpskommissionens anbefaling \#6 (Kilde: Hjemmehjolpskommissionen (2013)) 
Selvom der ikke blev skelnet i den praktiske gennemførsel af de individuelle TSH-forløb, var det af hensyn til den økonomiske styring nødvendigt at skelne mellem to typer TSH-forløb. For det første var der borgere, der ikke inden for det seneste år havde modtaget hjemmepleje. Denne målgruppe, som blev betegnet "nye borgere", omfattede forholdsvis mange, som efter en relativt begrænset indsats kunne forbedre deres funktionsevne. Omkring 60\% af målgruppen blev et halvt år efter fuldt ud selvhjulpne, defineret således at de ikke modtog kommunalt finansieret hjemmepleje, træning, sygepleje eller plejecenterplads.

For det andet var der "gamle borgere", dvs. borgere, som inden for det seneste år havde modtaget hjemmepleje. Borgerne i denne målgruppe modtog i højere grad også andre tilbud end hjemmepleje, f.eks. træningsindsatser. Deres potentiale for at opnå fuld selvhjulpenhed blev vurderet som mindre. Men fælles for begge målgrupper var, at de havde rehabiliteringspotentiale, og at visitationen vurderede, at de ved et TSH-forløb kunne blive i stand til at forbedre

\section{Tildelingsmodellen for TSH}

Den effektbaserede tildelingsmodel for et TSH-forløb var for det første baseret på, at der blev anvendt en forløbsbaseret bevilling (dvs. bevillingen var baseret på antallet af konkrete, visiterede TSH-forløb), og at bevillingen blev gjort effektbaseret (dvs. størrelsen af bevillingen var afhængig af effekten). Derfor blev der taget udgangspunkt i en bevillingsformel baseret på en forløbstakst (dvs. en bevilling for hele forløbet, når en TSH-indsats blev visiteret) samt en lineær effekttakst, så en del af bevillingen varierede med den opnåede effekt.

Effekten i modellen blev fastlagt som den procentuelle reduktion i udgiftsniveauet i forhold til det forventede udgiftsniveauet for den enkelte borger, hvis borgeren ikke gennemførte et TSH-forløb. Der var altså tale om, at økonomiske hensyn blev vægtet med $\lambda=100 \%$, således at:

$$
\text { Omkostningseffektivitet }=\frac{\text { udgiftsniveau }}{\text { forløbsomkostninger }}
$$

Udgiftsniveauet blev fastlagt som kommunens samlede udgifter ved de tilbud, borgeren modtog efter gennemførelsen af TSH-forløbet. I den konkrete effektmåling blev udgiftsniveauet vurderet i en periode efter det konkrete TSH-forløb samt en stabiliseringsperiode, dvs. en fast periode, i hvilken man antog, at udgiftsniveauet ville stabilisere sig og afspejle en mere langvarig effekt end under eller umiddelbart efter TSH-indsatsen. Det tidspunkt, hvor effekten blev beregnet, betegnes effekttidspunktet. Se figur 3.

Når økonomiske hensyn blev vægtet 100\%, var det dels et udtryk for, at den specifikke målgruppe havde potentiale til at blive selvhjulpne, og dels fordi hovedparten af de andre hensyn, der kunne 
være inddraget for denne målgruppe, blev vurderet at være nært forbundet med at være selvhjulpen. Vægtningen skulle altså ikke fortolkes således, at den individrettede effekt i form af bedre kvalitet, øget livskvalitet etc. skulle erstattes af kommunens besparelser, men den skulle i stedet ses som en faglig vurdering af effekten. En rehabiliteringsleder i kommunen udtrykte det således: "Det giver ikke forbedret livskvalitet, at en medarbejder fra kommunen kommer ud og giver dig strømper på, hvis du i stedet for selv kunne lære at gøre det”.

I sagens natur kan udgiften til den samme borger på samme tidspunkt med og uden et gennemført TSH-forløb ikke sammenlignes. Derfor blev effekten udregnet på baggrund af en beregnet reference (en baseline). Modellen blev fastlagt i to versioner, idet der som forklaret ovenfor blev skelnet mellem nye borgere (TSH1-modellen), som året forinden ikke havde modtaget hjemmepleje fra ÆHF, og gamle borgere, som inden for det seneste år havde modtaget hjemmepleje fra ÆHF (TSH2modellen). Fælles for de to modeller var, at taksterne blev fastlagt, så bevillingen ved forventet effektniveau (dvs. det udgiftsniveau der normalt eller hidtil havde kunnet realiseres efter en lignende indsats) netop svarede til den bevilling, der normalt ville blive givet til et gennemsnitligt, tilsvarende forløb. Da bevillingen var effektafhængig, betød det dermed, at den "forventede" bevilling kun blev opnået, hvis effekten var som forventet. Var effekten bedre, blev bevillingen større, og var effekten mindre, blev bevillingen mindre. Størrelsen af denne gennemsnitlige bevilling blev betegnet en normtakst og var dermed også den bevilling, der ville indgå i ÆHFs visitationsbudget for TSH.

I TSH-modellerne fastlagde man effektbaseline på baggrund af konkrete data i en estimeringsperiode, således at baselinen for gamle borgere i TSH2-modellen svarede til den specifikke borgers udgiftsniveau før TSH, justeret for forventet udgiftsudvikling frem til effekttidspunktet. I TSH1-modellen var effektbaselinen det forventede eller normale udgiftsniveau for en given borger, der på et tidligere tidspunkt, estimeringsperioden, havde modtaget en tilsvarende indsats. Selvom princippet ved de to modeller var ens, var det væsentligt, at baselinen i TSH2-modellen var den enkelte borgers forventede udgiftsniveau uden en TSH-indsats, da dette niveau kunne estimeres mere præcist end i TSH1-modellen, hvor baselinen var fastlagt på målgruppeniveau.

For at illustrere princippet ser vi nærmere på, hvordan taksterne blev fastlagt for TSH1-modellen: Normtaksten (altså den gennemsnitlige forløbsbevilling) blev fastlagt som den gennemsnitlige TSHudgift for de borgere, der indgik i beregningen af baseline (altså i en estimeringsperiode på et tidligere tidspunkt). Sammenhængen mellem begreberne illustreres i figur 3. 


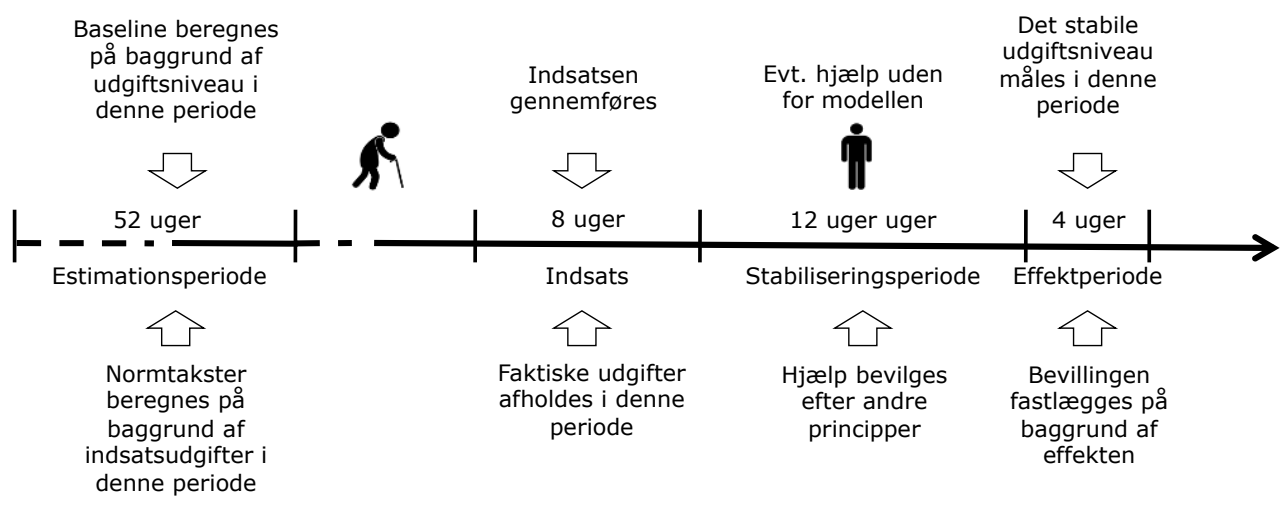

Figur 3: Grundprincippet for fastloeggelsen af den direkte effektbaserede tildeling til forløbet Traening som Hjolp i Aldre- og Handicapforvaltningen i Odense Kommune.

Da nye borgere var defineret som borgere, der ikke havde modtaget hjemmepleje det seneste år, var der ikke noget udgiftsniveau, før TSH blev iværksat, men på baggrund af omkring 400 lignende forløb afviklet året forinden (estimeringsperioden) blev der fastlagt en effektbaseline. Denne blev beregnet som det gennemsnitlige, faktiske udgiftsniveau i en ét-måneds effektperiode (omregnet til helårsniveau) efter 8 ugers TSH og en 3 måneders stabiliseringsperiode.

\section{Fastlæggelsen af taksterne}

Ved udviklingen af modellen tog man udgangspunkt i følgende data, som enten fandtes i ÆHF's ITsystemer, eller som kunne beregnes på baggrund af de data, der allerede fandtes:

I = normtakst, dvs. bevilling til intervention ved forventet TSH-effekt

$r \quad=$ risikofaktorer, der karakteriserer den enkelte borgers indsats og effektpotentiale

$I(r) \quad=$ normtakst, hvis omkostningen til indsatsen er afhængig af risikofaktorer, $r$

$E \quad=$ forventet økonomisk effekt, dvs. forventet reduktion i udgiftsniveau

$E(r) \quad=$ forventet økonomisk effekt, hvis denne er afhængig af risikofaktorer

$N \quad=$ antal borgere, der visiteres til TSH i den periode, som bevillingen vedrører

$F \quad=$ forløbsbevillingen udtrykt ved det beløb, der gives fast ved visitering af TSH-forløb

$\alpha=$ forløbsparameter, $0 \leq \alpha \leq 1$, som angiver den andel af bevillingen, som er fast

$\beta \quad=$ effekttakst, dvs. bevilling pr. opnået effektenhed.

Den mest simple, lineære incitamentsmodel forudsætter, at målgruppen er helt homogen, således at hverken omkostningerne til indsatser eller den forventede effekt er afhængige af nogen risikofaktorer, dvs. $I(r)=I$ og $E(r)=E$. Desuden forudsættes det i den simple version, at der kun anvendes ét effektmål. Hvis der anvendes en lineær incitamentsstruktur, således at den effektafhængige andel af tildelingen varierer proportionalt med effekten, vil modellen bestå af en 
forløbsbevilling, $F=\alpha \cdot I$, hvor $0 \leq \alpha \leq 1$, samt en effekttakst, $\beta$, således at parametrene fastlægges på baggrund af denne sammenhæng:

$$
I=\alpha I+\beta E=F+\beta E
$$

Da parametrene $\alpha$ og $\beta$ er bestemt ved en ligning med to ubekendte, betyder det i praksis, at man vælger én af parametrene og beregner den anden. I de første modeltest, som ÆHF gennemførte, blev effekten målt som udgiftsniveauet i effektperioden i forhold til baselinen i estimeringsperioden, jf. figur 3, således at $E$ blev målt i procentpoint. I modeltesten blev $\alpha$ besluttet, hvorefter $\beta$ blev beregnet: $\beta=(1-\alpha) I / E$. Hvis man eksempelvis fastlægger $\alpha=50 \%$, medfører det, at hvis $I=14.400$ kr., og $E=20$, så er $\beta=360 \mathrm{kr}$. for hvert procentpoint udgiftsniveauet afviger fra baselinen. Hvis man ønsker at holde $\beta$ fast, $\operatorname{kan} \alpha$ alternativt beregnes som: $\alpha=1-\beta E / I$. Eksempel: Hvis $I=14.400$ kr., $E=20$, og vi ønsker at sætte $\beta=200 \mathrm{kr}$., så bliver $\alpha=0,722$, således at forløbstaksten bliver $72,2 \%$ af normtaksten.

Ved udviklingen af TSH1-modellen var der især interesse for, om der var forskelle i indsatser og effekter som følge af køn $(s=m, k)$ eller alder $(a=18,19 \ldots)$, idet disse forhold blev udpeget som de relevante risikofaktorer ved projektets start. I andre typer modeller kunne der indgå andre risikofaktorer, f.eks. i form af traditionelle socioøkonomiske kriterier, og der ville kunne foretages en statistisk analyse for at vurdere, hvilke risikofaktorer der betinger udgiftsniveauet. Fortolket for TSH1-modellen ville den simple, lineære model afspejle, at der i estimeringsperioden ikke har været forskel på TSH-omkostningerne uanset køn og alder, og at effekten ligeledes er uafhængig af køn og alder. I den valgte model for nye borgere kunne det dog ved en nærmere analyse konstateres, at udgiftsniveauet var afhængigt af køn, men ikke alder, hvorfor sidstnævnte faktor blev udeladt i modeludviklingen.

\section{F. Periodebaserede indsatser}

De periodebaserede indsatser omfatter som nævnt længerevarende eller permanente aktiviteter. I princippet kan en længerevarende indsats omfatte vuggestue, børnehave og uddannelsesaktiviteter, hvor man i praksis vil kunne beregne udgiftsbehovet på baggrund af de konkrete aktiviteter, der forventes at indgå i indsatsen. På dagtilbudsområdet kan man f.eks. budgettere faste omkostninger til husleje etc. ud fra de forventede udgifter, ligesom variable omkostninger til løn etc. kan budgetteres ud fra normeringer. Tilsvarende indgår klasser, undervisningstimer etc. ofte i tildelingsmodeller på folkeskoleområdet. 
I dette afsnit vil vi for at eksemplificere princippet fokusere på permanente aktiviteter på ældre- og handicapområdet, hvor borgeren, medmindre der opstår en særlig forbedring, fraflytter kommunen eller afgår ved døden, vil fortsætte med at modtage tilbud fra kommunen. Det klassiske eksempel er indsatser rettet mod ældre borgere i eget hjem, som udover praktisk og personlig hjælp kan omfatte sygeplejeindsatser (herunder også medicindosering), træningsindsatser (f.eks. vedligeholdelsestræning), hjælpemidler etc. Når borgeren undervejs indgår i et tidsafgrænset rehabiliteringsforløb, vil det ofte betyde, at vedkommendes funktionsniveau kan bevares i længere tid, eller at behovet for hjælp måske kan reduceres. Men borgeren vil oftest fortsat modtage en eller anden form for kommunal indsats.

Tilsvarende kan permanente aktiviteter være borgere, der modtager bostøtte, f.eks. som følge af fysiske handicap eller psykiatriske problemstillinger. Behovet for støtte kan varierende over tid, og hvis der er tale om problemstillinger, som er vedvarende, kan indsatserne opfattes som permanente, men stadig variere i intensitet. Som nævnt af Jensen \& Olesen (2018b, pp. 340-342) vil der ofte også være tale om, at borgerne modtager andre tilbud fra kommunen, f.eks. væresteder og hjemmepleje. Endelig vil permanente indsatser også omfatte plejehjem og botil-bud samt i regionalt regi en række kronikerområder.

\section{Den traditionelle økonomistyring}

Traditionelt er økonomistyringen for permanente indsatser baseret på anvendelsen af den såkaldte Bestiller-Udfører-Modtager-model (BUM). Denne indebærer bl.a. en organisatorisk adskillelse af den afdeling, der bestiller aktiviteterne, og de afdelinger, der udfører dem. ${ }^{x}$ Afdelinger har typisk egne budgetter, således at bestilleren har et rammebudget, f.eks. til hjemmepleje, mens udførerne har et takstbaseret budget. Bestilleren beslutter ud fra lovgivning, kommunens kvalitetsstandarder og et fagligt skøn ved en visitation, hvilke tilbud en borger skal modtage, og hvilke indsatser denne skal bestå af, mens udføreren, som betegnelsen antyder, har ansvaret for at udføre aktiviteterne.

Det varierer kommunerne imellem, hvilke aktivitetsenheder der visiteres til. Selvom man ofte får det indtryk i medierne, at der i hjemmeplejen visiteres helt præcist i minutter pr. borger, er der i praksis tale om aktiviteter eller såkaldte pakker, der svarer til hjælp af en vis varighed. Ved anvendelse af en budgetteret timepris vil visitationsbeslutningen dermed kunne oversættes til en økonomisk bevilling. Hvis timeprisen f.eks. er 400 kr., og der er visiteret aktiviteter svarende til 1 times hjælp pr. uge, vil udføreren modtage en bevilling på $1 \cdot 52 \cdot 400 \mathrm{kr}$. $=20.800 \mathrm{kr}$. på årsniveau. Det kan være lidt mere kompliceret i praksis, og udførerenhedens budget kan også være delvist baseret på et fast budget, men grundprincippet er forholdsvist enkelt. Hvis borgerens situation ændrer sig, foretages en revisitering, og udførerens bevilling bliver tilsvarende ændret. 
Timelønnen i udførerenheden er naturligvis ikke 400 kr., idet der er tale om en intern afregningspris, som dels indeholder en budgetbaseret fordeling af kapacitetsomkostninger, og dels er baseret på en forventet effektivitet. Effektiviteten opgøres sædvanligvis ved en procentuel ATA-tid (Ansigt-TilAnsigt), som angiver den procentdel af en medarbejders tid, der anvendes på de borgerettede aktiviteter, som visitationsbeslutningen vedrører. Den resterende del af tiden udgøres af f.eks. dokumentation, møder, kursusaktiviteter og ikke mindst transporttid.

BUM-modellen udmærker sig ved enkelthed og transparens, og ledelsesrummene er forholdsvis klart defineret, hvad angår, hvilke beslutninger der kan træffes, hvad der er ansvar for, og hvilke konsekvenser beslutningerne har for afdelingernes økonomi. Ud fra en gennemsnitsbetragtning er modellen også egnet til at styre den overordnede kommunale økonomi, omend det kan være nok så vanskeligt for bestilleren at overholde budgettet, hvis flere borgere end forudsat har behov for hjælp, eller hvis omfanget af hjælpen er større end budgetforudsætningen. Tilsvarende øges udførerens udfordringer, hvis indsatsen kræver længere tid, end der er visiteret til, eller hvis den forudsatte effektivitet ikke kan realiseres.

Incitamentsstrukturen er på godt og ondt, relativ enkel: Bestilleren kan forbedre budgetoverholdelsen ved at visitere færre borgere til indsatser eller ved reducere til mindre ressourcekrævende indsatser, mens udføreren primært kan forbedre budgetoverholdelsen ved at øge effektiviteten, idet det forudsættes, at de aktiviteter, der er visiteret til, skal gennemføres. De to aktørers incitamenter er imidlertid også modsatrettede, hvilket kan vanskeliggøre samarbejdet. Hvis borgerens behov for hjælp stiger, vil udførerent ønske at bestilleren forøger bevillingen, hvilket vil forøge presset på bestillerens budget. Tilsvarende vil bestilleren ønske at reducere bevillingen, hvis borgeren bliver mere selvhjulpen, mens udføreren vil ønske at fastholde bevillingen. Dette ikke nødvendigvis, fordi udføreren ønsker en større bevilling end nødvendigt, men det vil ofte være relateret til, at visitationen til andre borgere ikke er blevet forøget tilstrækkeligt, eller fordi udgifterne ikke kan reduceres i samme takt, som bevillingen reduceres. I begge disse tilfælde vil udføreren være økonomisk presset og dermed have vanskeligt ved at afgive ressourcer.

De fleste kommuner anvender en integreret visitation, så den samme visitator har mulighed for at visitere til flere forskellige indsatser, hvilket fremmer et helhedsorienteret perspektiv, men for at sikre en specialiseret indsats vil forskellige typer indsatser ofte blive udført af forskellige udførerenheder, der af styringsmæssige årsager har adskilte budgetter. F.eks. kan hjemmepleje leveres af hjemmeplejeteams, bostøtte af en bostøtteafdeling, mens træningsindsatser kan udføres af en udkørende rehabiliteringsafdeling eller på træningscentre. Ofte vil sygeplejeydelser blive udført af en sygeplejeafdeling, der har et rammebudget, mens indsatser på beskyttede værksteder kan være ramme- eller takstfinansieret etc. Behovet for indsatser fra alle disse afdelinger kan variere over tid; nogle gange komplementerer (eller understøtter) de hinanden, og andre gange kan de være 
alternativer. Dermed indebærer den relativt enkle BUM-model reelt set en stor styringsmæssig kompleksitet.

\section{Periodebevillinger for permanente indsatser}

Fremfor at visitere konkret til indsatser kan man vælge at visitere til periodebaserede indsatser og tilsvarende anvende periodebevillinger, der dækker alle indsatserne i perioden. Det er dermed en form for bundled payment (Herzlinger \& Huang 2014; Porter \& Kaplan 2016). I den mest simple version vil der være tale om en periodetakst forstået som en fast månedlig bevilling pr. borger visiteret hertil. Denne periodetakst vil dermed udgøre en bevilling, der dækker alle udgifter forbundet med borgeren, uanset hvilke paragrafer indsatserne er bevilget efter, hvilke afdelinger der udfører indsatserne, eller hvilken faglig baggrund medarbejderne har. Dermed kan budgettet for den udførerenhed, der er ansvarlig for indsatsen fastlægges som $N \cdot P$, idet

$N=$ antal borgere, der visiteres til indsatser i den periode, som bevillingen vedrører $P=$ periodebevillingen udtrykt ved det beløb, der gives pr. periode.

Som Jensen \& Olesen (2018b) viser, kan der eksempelvis være tale om, at indsatserne omfatter aktiviteter på det socialpsykiatriske bostøtteområde, således at periodebevillingen beregnes på følgende måde:

Målgruppen bestod af godt 100 borgere, der dels modtog bostøtte (ift. SEL § 85) i Område Vest, dels typisk også modtog andre indsatstyper som beskyttet beskæftigelse, aktivitets- og samværstilbud, værestedstilbud samt hjemmepleje (SEL § 83). Ud fra en baselineperiode blev der udarbejdet en fast enhedstakst, fastlagt som en gennemsnitstakst for alle indsatser i forhold til målgruppen. (Jensen \& Olesen, 2018b, p. 340).

Hvis ikke alle de borgerrelaterede aktiviteter, som budgettet omfatter, udføres af den forløbsansvarlige enhed, indebærer princippet, at der skal foretages en intern betaling eller afregning til de enheder, der udfører aktiviteten. Som angivet ovenfor er periodebevillingen en gennemsnitstakst, og udgifterne forbundet med de enkelte borgere vil dermed både kunne være større eller mindre end gennemsnittet. Det medfører, at hensigtsmæssigheden af bevillingsprincippet skal vurderes i forhold til den forøgede finansielle risiko for udførerenheden, som tildelingsprincippet indebærer. Denne såkaldte budgetrisiko (Smith 2008, p. 104ff) afhænger både af antallet af borgere, der er visiteret til forløbet, og af udgifternes varians på borgerniveau (Baxter et al. 2000; Bojke et al. 2001).

Hvis variationen i de borgerspecifikke udgifter afhænger af kendte risikofaktorer, f.eks. alder eller specifikke diagnoser, vil periodetaksten kunne gøres afhængig af disse faktorer, således at der 
anvendes risikojusterede periodetakster. Som alle tildelingsmodeller forudsætter modellen, at de borgerforløb, der indgår i takstberegningen, gennemsnitligt har samme udgiftsniveau som de forløb, der efterfølgende visiteres til. Det betyder i praksis, at den samlede konsekvens af (a) udgiftsniveauet for borgere, der førstegangs-visiteres til forløbet, (b) udgiftsniveauet for borgere, der udgår af forløbet ved f.eks. fraflytning, død eller udvisitering, samt (c) ændringer i udgiftsniveauet for borgere i forløbet, ikke betyder en ændring i det gennemsnitlige udgiftsniveau.

\section{Individuelle forløbsbevillinger}

Der kan imidlertid også være forløbstyper, hvor der enten er så få borgere i forløbet eller så stor udgiftsvarians, at en fast forløbsbevilling vil indebære en for stor budgetusikkerhed. I sådanne tilfælde kan det være nødvendigt at anvende individuelle forløbsbevillinger for at nedbringe budgetrisikoen. Figur 4 illustrerer dette princip, som desuden adresserer tre praktiske problemstillinger. For det første kan der være forløbstyper, f.eks. botilbud, hvor der dels er relativt få borgerforløb, stor udgiftsvariation og dels relativt høje takster. Dette vil indebære en høj budgetrisiko for udførerenheden, hvis der anvendes takster baseret på gennemsnitsomkostninger.

For det andet vil driften af tilbud med sådanne forløb blive udfordret af, at køberkommunerne vil have en tilbøjelighed til primært at vælge sådanne tilbud, når udgifterne forbundet med borgeren er højere end taksten (hvis denne er fastlagt ud fra gennemsnitsomkostningerne pr. borger). Da tilbuddets omkostninger over tid vil blive tilpasset til de beboere, der faktisk er indskrevet, vil omkostningerne stige, og hvis taksterne skal afspejle gennemsnitsomkosningerne, vil disse ligeledes stige. Dermed vil der være færre borgere, som er mindre ressourcekrævende end taksten, tilbuddet vil blive mindre efterspurgt, der vil opstå ledige pladser, og kapacitetsomkostningerne kan ikke dækkes af taksterne, som skal sættes yderligere op. For at undgå disse dysfunktionelle dynamikker er det nødvendigt at differentiere taksterne og eventuelt gøre dem borgerspecifikke.

For det tredje kan der ved indførelsen af en ny forløbsbaseret tildelingsmodel være behov for at kunne dokumentere, at tildelingen svarer til udgiftsniveauet for de borgere, der ved opstarten af den nye tildelingsmodel, allerede er placeret i forløbet. I tilknytning hertil kan der være behov for at kunne vise, hvordan den nye tildelingsmodel ændrer tildelingen imellem forskellige forløbstyper, eller hvordan forskellige kommuners betaling for borgere i det samme tilbud påvirkes. 


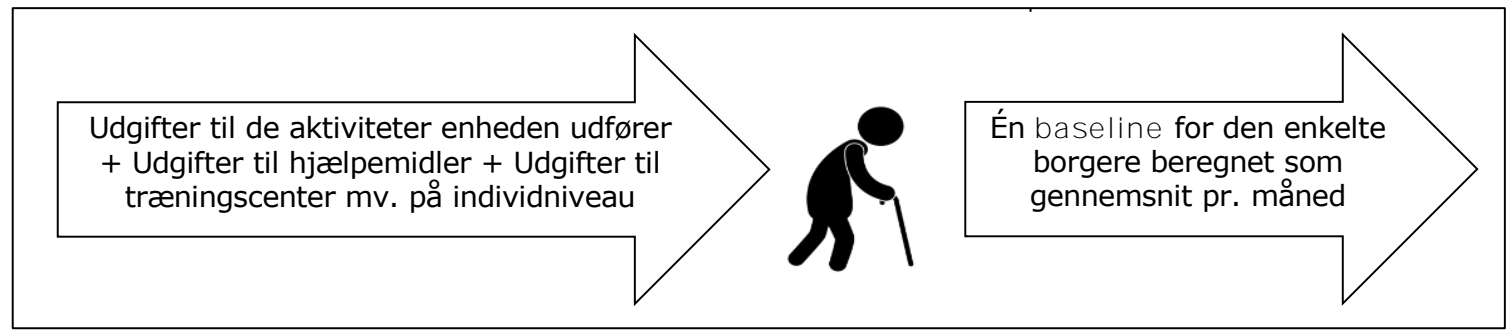

Figur 4:Etableringen af en borgerspecifik baseline for udgiftsniveau.

(Kilde: internt materiale, Aldre- og Handicapforvaltningen, Odense Kommune).

Udover de situationer, som er nævnt ovenfor, vil der i mere avancerede, økonomiske styringsmodeller, hvor der anvendes direkte effektbaseret økonomistyring, kunne være behov for at anvende borgerspecifikke udgiftsbaselines som bevillingsniveau, når borgeren visiteres til forløbet. Et eksempel er, hvis borgeren visiteres til en permanent indsats efter gennemførelsen af et kortere og intensivt rehabiliteringsforløb, og hvor der efter afslutningen af forløbet foretages en mere omfattende udredning, hvor det konkrete indsatsbehov fastlægges ved en visitationsbeslutning.

Princippet illustreres i figur 5, hvor borgeren indplaceres i bevillingsmodellen på et specifikt udgiftsniveau ved "modelstart". Dette udgiftsniveau kan i princippet (1) være bestemt ved en udredning efter et rehabiliteringsforløb, (2) være baseret på de individuelt visiterede ydelser, borgeren har modtaget i en tidligere periode, eller (3) være aftalt ved forhandling mellem bestiller og udfører. Det er i figur 5 illustreret, at udgiften i forløbet kan være stigende over tid, således at baselinen fremskrives med en stigningstakt, $\partial$, der i figuren dels er fastlagt for hele forløbet, dels er forudsat at være lineær.

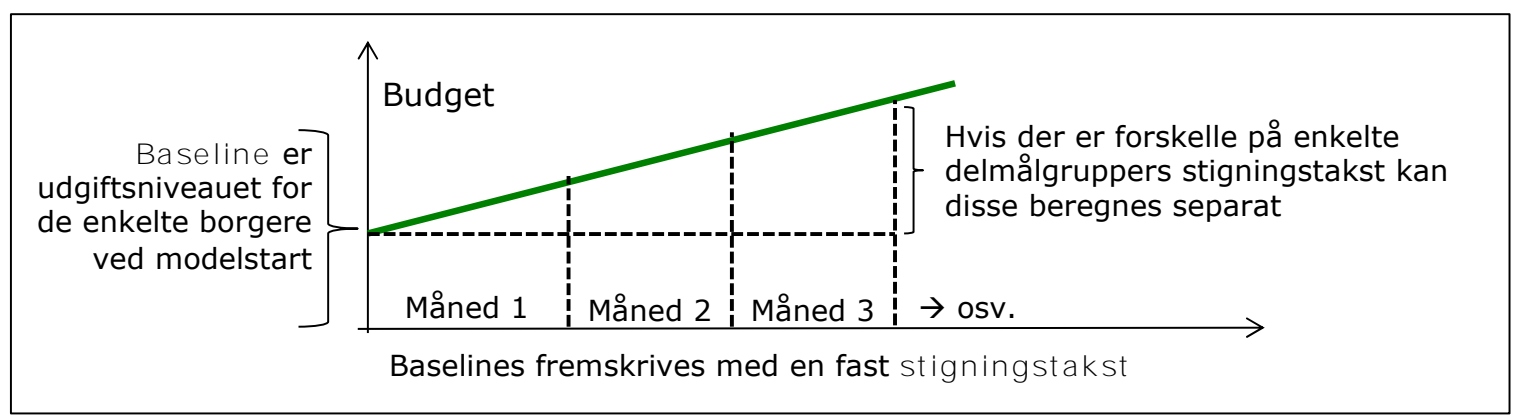

Figur 5: Skitse af principperne bag en tildelingsmodel for periodebasererede indsatser på celdreområdet (Kilde: internt materiale, Aldre- og Handicapforvaltningen, Odense Kommune)

I praksis kan $\partial$ estimeres på baggrund af udviklingen i det individuelle udgiftsniveau for en tilsvarende målgruppe i en tidligere periode; svarende til grundprincippet vist i figur 3. Afhængig 
af målgruppen, herunder borgernes rehabiliteringspotentiale, kan $\partial$ være både positiv og negativ, ligesom $\partial=0$ svarer til, at udgiftsbehovet er uændret over tid. Den faste forløbstakst anvendt i tildelingsmodellen på det socialpsykiatriske bostøtteområde i Odense Kommune, jf. ovenfor, kunne i princippet fortolkes som en variant af modellen vist i figur 5 , hvor $\partial=0$, og hvor alle borgerne visiteres til samme udgiftsniveau. I praksis vil der være relativt store forskelle i udgiftsniveauet borgerne imellem, men da antallet af borgere i målgruppen var forholdsvis stort ${ }^{\mathrm{xi}}$, blev det vurderet, at indplacering på et gennemsnitligt udgiftsniveau gav en tilstrækkelig præcision.

Hvis der skal anvendes en effektbaseret tildeling, hvor udgiftsniveau indgår som et tildelingskriterie, vil $\partial$ være den centrale parameter, idet en ændring i $\partial$ afspejler en effektændring. I testperioden havde modellen, som Jensen \& Olesen (2018b) beskriver, ikke direkte indbygget en effektafhængig incitamentsstruktur, men da det samtidig blev besluttet, at de ressourcer, der ville blive frigjort, kunne anvendes til andre indsatser til andre borgere, som udførerenheden havde ansvaret for, var der derfor tale om en indirekte effektbaseret økonomistyring.

\section{G. Afsluttende bemærkninger}

Det er nødvendigt, at vi i den offentlige sektor kan opnå mere for mindre, som det populært siges. Det indebærer ikke blot, at produktiviteten skal øges, men det betyder i særdeleshed, at de offentlige aktiviteter skal have en bedre effekt. Det må dog overvejes, hvilke effekter vi ønsker, og hvad ændringerne i velfærdssamfundet vil betyde for de effekter, der skal prioriteres? Det er i bund og grund politiske spørgsmål, og det er derfor afgørende, at effektdiskussionen og -prioriteringen kommer på den politiske dagsorden. Der skal desuden skabes nye strategiske og ledelsesmæssige sammenhænge mellem det politiske niveau, borgernes ønsker og frontlinjemedarbejdernes handlinger.

Vi har med denne artikel præsenteret nogle rammer for, hvordan effektbaseret økonomistyring kan forstås, og hvordan de sædvanlige tildelingsmodeller i den offentlige sektor kan udvikles, så der indgår mere eksplicitte hensyn til omkostningseffektivitet. Der er mange vanskeligheder, der skal håndteres, og nye udfordringer vil dukke op. Blandt de helt centrale problemstillinger er, hvilke implikationer et effektbaseret fokus har for organisering og økonomistyring. Ældre- og Handicapforvaltningen i Odense Kommune (Jensen \& Olesen 2018a) valgte en radikal omorganisering med borgerforløbene som omdrejningspunkt, mens andre kommuner og regioner går lidt mere forsigtigt til værks.

I artiklen argumenterede vi for, at serviceproduktionen i den offentlige sektor kan karakteriseres ved forskellige produktionsstrukturer, idet vi især lagde vægt på forløbs- og periodebaserede 
produktionsstrukturer. Desuden illustrerede vi med udgangspunkt i erfaringer fra Ældre- og Handicapforvaltningen i Odense Kommune, dels hvordan de to produktionsstrukturer kunne indebære forskellige tildelingsmodeller, og dels hvordan effektbaserede tildelingsprincipper kunne udvikles i praksis. Når nye styringsprincipper indføres, rejser det et spørgsmål om, hvorvidt de er bedre end dem, de erstatter. Det er et kompliceret spørgsmål, fordi der i praksis ændres mange ting på én gang, og fordi offentlige organisationer kan vurderes ud fra mange perspektiver og kriterier. Vi har i artiklen taget udgangspunkt i et ledelsesperspektiv, således at tildelingsmodeller anvendes til opnå ledelsens målsætninger. Derfor kunne én måde at få svar på spørgsmålet være simpelthen at spørge ledelsen. Men andre interessenter har også legitime interesser i, hvordan organisationen fungerer, og hvilke konsekvenser styringen har. Derfor er det også relevant at stille spørgsmålet til medarbejderne og brugerne. Ud fra et kriterie om omkostningseffektivitet er det også vigtigt at se på, om en ændret styring faktisk har betydet, at effekten er blevet bedre, eller at omkostningerne er reduceret. Vi har ikke haft mulighed for at lave sådanne vurderinger. Desuden kompliceres spørgsmålet i høj grad af, at faglige praksisser, organisationsprincipper og styringsprincipper samtidig ændres. Hvis noget bliver bedre eller dårligere, hvad skyldes det så? Selvom det kan være kompliceret at afgøre, hvilke konsekvenser ændrede styringsprincipper har, er det ikke desto mindre vigtige spørgsmål, og der vil være brug for forskningsbaserede studier af offentlige virksomheder, der indfører nye tildelingsprincipper.

Det er et fællestræk for de modeller, vi har præsenteret her i artiklen, at de kræver individbasererede data for både effekt og udgifter. Det udfordrer de bestående registreringssystemer og datastrukturer. Registreringen af udgifter og omkostninger foretages eksempelvis i kommunerne efter det autoriserede budget- og regnskabssystem, som omfatter et sæt af regler vedrørende formen for kommunernes årsbudget, flerårige budgetoverslag og regnskaber m.v. Den autoriserede kontoplan indebærer, at der især er fokus på steds- og artskontering samt på formål (inkl. opgaver og lovhjemmel). ${ }^{\text {xii }}$

Der er ofte mindre fokus på at registrere og fordele udgifter til forløb og konkrete indsatser og aktiviteter, ligesom individer ikke anvendes systematisk som konteringsobjekt i økonomistyringen. Det gør det vanskeligere at udvikle en egnet effektbaseret økonomistyring - og det skaber faktisk også vanskeligheder, når kommuner forsøger at idenficere forbedringspotentialer ved at sammenligne sine udgiftsniveauer med andre kommuner. Man kan ganske vist benchmarke omkostninger pr. borger eller det gennemsnitlige antal foranstaltninger pr. paragraf med andre kommuner, men man kan ikke afgøre heraf, hvad de nødvendige udgifter i den konkrete kommune er. Ligeledes giver benchmarkdata heller ikke svar på, hvad der er rimeligt ud fra konkrete politiske prioriteringer i den enkelte kommune. 
Uanset hvor meget man forfiner og ensretter den fælleskommunale kontoplan, er økonomital åbne for fortolkninger og alternative forståelser. Er det godt, at mange borgere i én kommune er indskrevet på botilbud sammenlignet med andre kommuner? Eller betyder det, at man har været dårlig til forebyggende og rehabiliterende arbejde i kommunen? Er det et problem, at udgifterne til bostøtte stiger, eller er det udtryk for, at man er godt i gang med at skabe værdige rammer for borgernes liv i eget hjem? For at kunne svare på sådanne spørgsmål er det nødvendigt at have data for både udgifter og effekter på individniveau, og det er samme datagrundlag, der er brug for, når der skal udvikles effektbaserede økonomistyringsmodeller.

\section{Om forfatterne}

Per Nikolaj Bukh (www.pnbukh.com) er cand.oecon. og ph.d. samt professor i økonomistyring ved Aalborg Universitet. Han har en omfattende erfaring med strategi og styring og har medvirket ved implementeringen af effektbaseret økonomistyring i en række offentlige virksomheder. Herudover har han udgivet mere end 20 bøger og en mængde artikler.

Karina Skovvang Christensen er cand.oecon. og ph.d. samt lektor ved Institut for Økonomi, Aarhus Universitet, hvor hun blandt andet beskæftiger sig med budgetlægning og økonomiske incitamenter i offentlige virksomheder. Hun har tidligere sammen med Per Nikolaj udgivet bogen Strategi og styring med effekt (Djøf Forlag, 2018) samt en række andre bøger og artikler om ledelse, styring og strategi.

\section{Referencer}

Andersen, L. B., C. B. Jacobsen, M. L. F. Jakobsen, T. Pallesen \& S. Serritzslew. (2017). Økonomiske incitamenter $i$ den offentlige sektor, 2. udgave. København: Hans Reitzels Forlag. https://doi.org/10.7146/politica.v38i4.69974

Andersen, L. B. \& L. H. Pedersen (2014). Styring og motivation i den offentlige sektor. København: Jurist- og Økonomiforbundets Forlag. https://doi.org/10.7146/politica.v24i1.69393

Andersen, M. \& C. Rohde. (2017). Virksomhedens økonomistyring, 5. udgave. København: Djøf Forlag. Baxter, K., M. Bachmann \& G. Bevan. (2000). Primary care groups: trade-offs in managing budgets and risks. Public Money and Management, Vol. 20, No. 1, pp. 53-62. https://doi.org/10.1111/14679302.00202

Bech, M. (2008). Hvad ved vi om økonomiske incitamenter? Ugeskrift for Lager, Vol. 170, No. 47, pp. 3874-3875. 
Bech, M. \& K. M. Pedersen. (2006). Not just for the money: Optimal incitamentsstyring er at bruge de typer af økonomiske og ikke-økonomiske incitamenter, som bidrager mest til medarbejdernes motivation. Tidsskrift for Sundhedsvoesen, Vol. 82, No. 4, pp. 147-150.

Bevan, G. \& C. Hood. (2006). What's measured is what matters: targets and gaming in the English public health care system. Public Administration, 84(3):517-538. https://doi.org/10.1111/j.14679299.2006.00600.x

Bjerregaard, H. H. \& P. H. Christensen. (2018). Værdibaseret styring af ortopædkirurgien i Region Nordjylland. I Strategi og styring med effekt, P. N. Bukh \& K. S. Christensen (eds.). København: Djøf Forlag.

Bojke, C., H. Gravelle \& D. Wilkin. (2001). Is bigger better for primary care groups and trusts? British Medical Journal, Vol. 322, pp. 599-602. https://doi.org/10.1136/bmj.323.7303.49

Bukh, P. N. \& K. S. Christensen (2018a). Ledelsesrummet er et ansvar - og det vokser. Offentlig Ledelse, nr. 2/2018.

Bukh, P. N. \& K. S. Christensen. (2018b). Strategi og styring med effekt: Danske erfaringer. København: Djøf Forlag.

Bukh, P. N. \& K. S. Christensen (2018c). Effektbaseret Økonomistyring. Nordisk Administrativt Tidsskrift, Vol. 95, No. 2, pp. 53-66.

Bukh, P. N. \& K. S. Christensen. (2018d). Effektbaserte budsjettmodeller i offentlig sektor. Magma, nr. 6, pp. 34-42.

Bukh, P. N. \& K. S. Christensen. (2019). Fremtidens økonomistyring er effektbaseret. Administrativ Debat, januar/2019, pp. 23-26.

Bukh, P. N. \& K. S. Christensen. (2020). Tildelingsmodeller og effektbaserede principper i den offentlige sektor. Samfundslederskab i Skandinavien, 35(4):207-249.

https://doi.org/10.22439/sis.v35i4.6019

Bukh, P.N. \& L.G. Dietrichson. (2010). Omkostningsregnskabets rolle i

økonomistyringen. I Økonomistyring, Per Nikolaj Bukh (ed.). København: Børsen Forum.

Bukh, P. N., K. S. Christensen \& A. K. Svanholt. (2020a). Omkostningsbevidsthed i socialt arbejde: fra spændingsfelt til professionalisme. Tidsskrift for Professionsstudier. nr. 31, september 2020.

Bukh, P. N., K. S. Christensen \& A. K. Svanholt (2020b). Making sense of cost-consciousness in social work. Qualitative Research in Accounting \& Management.

Bukh, P. N. \& P. Israelsen. (2004). Activity Based Costing - Dansk økonomistyring under forvandling. København: Jurist- og Økonomforbundets Forlag. https://doi.org/10.7146/politica.v20i1.68960 
Bukh, P. N. \& A. K. Svanholt. (2019). Styring i spændingsfeltet mellem vilde problemer og stramme budgetter. Samfundslederskab i Skandinavien, Vol. 34, No. 3, pp. 229-266.

https://doi.org/10.22439/sis.v34i3.5812

Bukh, P. N. \& A. K. Svanholt. (2020). Empowering Middle Managers in Social Services Using Management Control Systems. Journal of Public Budgeting, Accounting \& Financial Management, Vol. 32, No. 2, pp. 267-289. https://doi.org/10.1108/JPBAFM-06-2019-0096

Burns, T. \& G. M. Stalker. (1961). The management of innovation. London: Tavistock.

Chenhall, R. S. (2007). Theorizing contingencies in management accounting research. I Handbook of Management Accounting Research, vol. 1, C. S. Chapman, A. G. Hopwood \& M. S. Shields (eds.). Amsterdam: Elsevier.

Christensen, K. S. \& P. N. Bukh. (2018). Effektbaseret økonomistyring på vej i den offentlige sektor. Revision \& Regnskabsvaesen, No. 8, pp. 28-41.

Dalsgaard, C. T., M. Kjærgaard \& K. Lemvigh. (2020). Økonomistyring af hjemmepleje og rehabiliteringsforløb, august 2020, VIVE, København.

Danske Regioner. (2016). Beskrivelse af afregningsmodeller til at understøtte værdibaseret styring. Arbejdspapir, Arbejdsgruppen for økonomi, afregningsmodeller og data i projektet om værdibaseret styring, Danske Regioner, december 2016.

Ekeroth, T. (2014). Hvad vil du gerne kunne? Danske Kommuner, No. 24/2014, pp. 12-17.

Frey, B. S. (1997). Not just for the money: an economic theory of personal motivation. Cheltenham: Elgar.

Galbraith, J. (1977) Designing complex organizations. Reading, MA: Addison-Wesley.

Hansen, C.-A. (2015). Bestiller-Udfører-Modtager-modellen (BUM) og kontraktstyring. I Kommunal økonomistyring på det sociale område, P. Bundesen \& C.-A. Hansen (eds.). København: Hans Reitzels Forlag.

Heckhausen, J. \& H. Heckhausen. (2008). Motivation and Action, Cambrige: Cambridge University Press.

Heeager, A. (2017). Placering af økonomisk beslutningskompetence internt i danske kommuner. Politica, Vol. 49, No. 1, pp. 47-67.

Herzlinger, R. E. \& C. Huang. (2014). Note on bundled payment in health care. Harvard Business School, Note \#9-312-032.

Hjemmehjælpskommissionen. (2013). Fremtidens hjemmehjælp - ældres ressourcer i centrum for en sammenhængende indsats, Rapport, Hjemmehjælpskommissionen, juli 2013. 
Holmgaard, A. P. (2014). Velfoerd under ombygning: fra service til selvstoendighed. København: Gyldendal Business.

Houlberg, K. (2017). Lokale styringsvilkårs betydning for kommunernes økonomiske styring fungerer sanktionslovgivningen som brandtæppe eller ilttelt? Politica, Vol. 50, No. 1, pp. 45-64.

Jacobsen, C. B. \& M. L. F. Jakobsen. (2014). Offentlig styring og koordination. I Offentlig forvaltning - et politologisk perspektiv. J. Blom-Hansen, P. M. Christiansen, T. Pallesen og S. Serritzlew (eds.). København: Hans Reitzels Forlag, pp. 52-77. https://doi.org/10.7146/politica.v28i1.68012

Jensen, T. K. \& K. D. Olesen. (2018a). Det effektbaserede styringsparadigme i Odense Kommune. I Strategi og styring med effekt, P. N. Bukh \& K. S. Christensen (eds.). København: Djøf Forlag.

Jensen, T. K. \& K. D. Olesen. (2018b). Design og test af effektbaserede økonomimodeller. I Strategi og styring med effekt, P. N. Bukh \& K. S. Christensen (eds.). København: Djøf Forlag.

Kerr, S. (1975). On the folly of rewarding A while hoping for B. Academy of Management Journal, Vol. 18, No. 4, pp. 769-783. https://doi.org/10.5465/255378

Kjellberg, P. K., J. Kjellberg, R. Ibsen \& L. T. Christensen (2012). Hverdagsrehabilitering i praksis. Erfaringer fra Fredericia 2008-2010. Ergoterapeuten, No. 1, pp. 5-9.

Kjærgaard, M., C. T. Dalsgaard, B. Panduro \& K. Lemvigh. (2018). Økonomistyring af tværgående løsninger: Inspiration til kommunernes økonomistyring af tværgående løsninger målrettet udsatte familier. VIVE, København.

KL. (2006). Den modificerede BUM-model: Nye udfordringer og muligheder for sociale institutioner, KL, København.

Kristensen, S. (2018). Differentieret budgettildeling som styringsværktøj og dialogredskab. I Strategi og styring med effekt, P. N. Bukh \& K. S. Christensen (eds.). København: Djøf Forlag.

Latham, G. P. (2007), Work motivation: history, theory, research and practice. Thousand Oaks: Sage Publications.

Locke, E. A. \& G. P. Latham. (1990). A Theory of Goal Setting \& Task Performance. New Jersey: Englewood Cliffs.

Mayston, D. J. (1998). Devolved Budgeting, Formula Funding and Equity. Management Accounting Research, Vol. 9, pp. 37-54. https://doi.org/10.1006/mare.1997.0069

Melander, P. (1994). Økonomistyringens dilemmaer og drivkræfter - fra økonomisk beslutningslogik til politisk multicentreret kamparena. Ledelse \& Erhvervsøkonomi, Vol. 58, No. 3, pp. 151-168. 
Mouritsen, J. (1987). Det styringsorienterede og det situationsbetingede regnskabsvæsen: to perspektiver på udformning af økonomistyringssystemer. Økonomistyring \& Informatik, Vol. 3, No. 1, pp. 27-43.

Mouritsen, J. (2018). Formål og mål i New Public Management - ressource, begrænsning, trivialitet eller byrde? Samfundslederskab i Skandinavien, Vol. 33, No. 3, pp. 222-18.

https://doi.org/10.22439/sis.v33i3.5551

Odense Kommune. (2014). Effektbaseret økonomistyring: Effektmål, indikatorer og økonomimodeller, Økonomisk Styring og Analyse, Ældre- og Handicapforvaltningen, Odense Kommune (internt notat). https://doi.org/10.7577/nibr/notat/2012/107

Otley, D. T. (1980). The contingency theory of management accounting: achievement and prognosis. Accounting, Organizations and Society, Vol. 4, pp. 413-428.

https://doi.org/10.1016/0361-3682(80)90040-9

Pedersen, N. J. M. (2016). Tendenser i stat-kommuneforholdet efter kommunalreformen - fokus på økonomiaftaler og sanktionssystemet. Politik, Vol. 19, No. $^{2}$, pp. 55-77 https://doi.org/10.7146/politik.v19i2.27406

Porter, M. E. \& R. S. Kaplan. (2016). How to pay for health care. Harvard Business Review, Vol. 94, No. 7, pp. 88-100.

Produktivitetskommissionen. (2013). Styring, ledelse og motivation i den offentlige sektor, analyserapport 3, september 2013, København.

Social- og Indenrigsministeriet (2019). Rehabilitering på ældreområdet efter §83a i serviceloven, Social- og Indenrigsministeriets Benchmarkingenhed, oktober 2019, København.

Smith, P. C. (2007). Formula funding of public services. Oxon: Routledge.

Smith, P. C. (2008). Formula funding of health services: learning from experience in some developed countries. Discussion paper No. 1/2008, World Health Organization, Geneva.

Thompson, J. D. (1967). Organizations in action. New York: McGraw-Hill.

Thomsen, M.T. (2020). Hvad er effektbaseret økonomistyring? KL Nyhedsbrev, kl.dk, https://www.kl.dk/nyheder/os/2020/marts/nr-203-april-2020/hvordan-kan-man-arbejde-medeffektbaseret-oekonomistyring-i-design-af-tildelingsmodeller - (tilgået 2. september 2020)

Thorball, K. B. (2018). Datadrevne beslutninger og velfærdsanalyse. I Strategi og styring med effekt, P. N. Bukh \& K. S. Christensen (eds.). København: Djøf Forlag. 
${ }^{\text {i }}$ Tak til Preben Melander samt en anonym reviewer for meget konstruktive og brugbare kommentarer til en tidligere version af artiklen. Ligeledes vil vi gerne takke Betina Sørensen for hjælp med manuskriptet. Endelig skylder vi en stor tak til flere studerende ved MPG-uddannelsen på Aalborg Universitet for deres mange gode spørgsmål til en tidligere version af artiklen

${ }^{i i}$ I Danmark har deciderede produktionsvirksomheder normalt kun været offentligt ejede af historiske årsager, eller hvis produktionen har været opfattet som samfundskritisk. Eksempelvis blev Den militære Klædefabrik i Usserød, der var overtaget af staten i 1802 for at sikre forsyningen af uniformsklæde, udskilt fra staten i 1990'erne. Ligeledes blev produktionen af vacciner ved Seruminstituttet frasolgt i 2016, da produktionen var urentabel, og da man på dette tidspunkt mente, at markedet kunne forsyne Danmark med de nødvendige vacciner.

iii Både Houlberg (2017) og Pedersen (2016) beskriver de statslige krav til kommunernes budgetoverholdelse samt de statslige sanktioner, der er forbundet med at overskride budgetterne.

iv I andre dele af den offentlige sektor end kommuner og regioner gælder andre forhold, som man naturligvis skal være opmærksom på. De selvejende uddannelsesinstitutioner fungerer således i praksis meget lig private virksomheder, idet de både har egenkapital og adgang til lånefinansiering.

${ }^{v}$ Både Houlberg (2017) og Pedersen (2016) beskriver de statslige krav til kommunernes budgetoverholdelse samt de statslige sanktioner, der er forbundet med at overskride budgetterne.

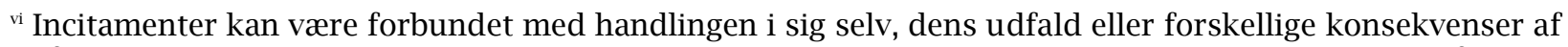
udfaldet (Heckhausen \& Heckhausen 2008). De incitamenter, der vedrører selve handlingen eller udfaldet betegnes indre incitamenter, mens de incitamenter, der er relateret til konsekvenserne af handlingen betegnes ydre incitamenter. Tilsvarende betegnes den motivation, som de to typer incitamenter er knyttet til for indre hhv. ydre motivation. Se desuden Latham (2007) samt Locke \& Latham (1990) for en omfattende beskrivelse af, den rolle, som mål har for motivation.

vii En kapitafinansering er et såkaldt risikojusteret beløb ('capitation funding'), f.eks. til et antal borgere i et distrikt, der er omfattet af tildelingen. Risikojusteringen indebærer, at der er taget højde for forskellene i det forventede udgiftsniveau distrikterne imellem. Se også Bukh \& Christensen (2020) samt Smith (2007).

viii Vi har vist vægtningen af udgiftsniveau og kvalitet for en forløbsbaseret indsats, hvor effekt sammenholdes med forløbsomkostninger. Der kan på samme måde foretages en vægtning af effektmål i forhold til periodeomkostninger.

${ }^{\text {ix }}$ Anvendelsen af TSH-modellen samt principperne for den effektbaserede økonomistyring i Odense Kommune er beskrevet mere detaljeret af Jensen \& Olesen (2018a, 2018b). Se også Hjemmehjælpskommissionen (2013, p. 95-97), Odense Kommune (2014), Thomsen (2020) samt Holmgaard (2014).

${ }^{x}$ Hansen (2015) beskriver BUM-modellen på det sociale område, og KL (2006) foreslår forskellige modifikationer af den klassiske BUM-model. Se desuden Kristensen (2018) for et eksempel samt Bukh \& Svanholt (2019) for en mere detaljeret analyse af den økonomiske styring, når BUM-modellen anvendes.

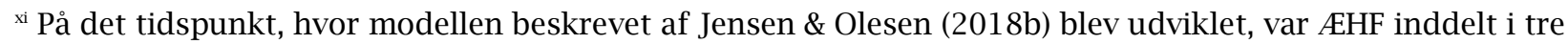
distrikter. Den beskrevne modeludvikling var baseret på en stikprøve på 100 borgere i Distrikt Vest, men antallet af borgere i målgruppen var langt større for den samlede kommune

xii Se f.eks. Andersen \& Rohde (2017), Bukh \& Israelsen (2004, kapitel 5) eller Bukh \& Dietrichson (2010) for en beskrivelse af kontoplanens dimensioner og disses anvendelse i økonomistyringen. 